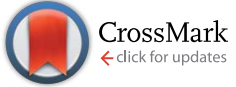

Cite this: J. Anal. At. Spectrom., 2015, 30, 2074

Received 27th March 2015 Accepted 13th July 2015

DOI: $10.1039 / c 5 j a 00105 f$

www.rsc.org/jaas

\section{Speciation of inorganic arsenic in particulate matter by combining HPLC/ICP-MS and XANES analyses}

\author{
K. Tirez, ${ }^{* a}$ C. Vanhoof, ${ }^{a}$ J. Peters, ${ }^{a}$ L. Geerts, ${ }^{a}$ N. Bleux, ${ }^{a}$ E. Adriaenssens, ${ }^{b}$ E. Roekens, ${ }^{b}$ \\ S. Smolek, ${ }^{d}$ A. Maderitsch, ${ }^{d}$ R. Steininger, ${ }^{e}$ J. Göttlicher, ${ }^{e}$ F. Meirer, ${ }^{c}$ C. Streli ${ }^{d}$ \\ and P. Berghmans ${ }^{a}$
}

Inorganic arsenic species in ambient particulate matter $\left(\mathrm{PM}_{10}\right.$ and $\left.\mathrm{PM}_{2.5}\right)$ have been determined in an urban area, in the vicinity of a metallurgical industrial plant. The developed high performance liquid chromatography inductively coupled plasma mass spectrometry (HPLC/ICP-MS) method allows monitoring of particulate $\mathrm{As}(\mathrm{III})$ and $\mathrm{As}(\mathrm{V})$-species, with a limit of quantification of $0.34 \mathrm{ng} \mathrm{m}^{-3} \mathrm{As}(\mathrm{II})$ and $0.23 \mathrm{ng} \mathrm{m}^{-3} \mathrm{As}(\mathrm{V})$, respectively. Good agreement was obtained between the sum of the concentrations of $\mathrm{As}(\mathrm{III})$ and $\mathrm{As}(\mathrm{V})$ determined by HPLC/ICP-MS and the total As concentrations determined by XRF, indicating a complete extraction of the As species. During the measuring campaigns for $\mathrm{PM}_{10}$ and $P M_{2.5}$, a significant conversion (oxidation) up to $54 \%$ of exogenous spiked As(III) was observed. The total amount of the spiked $A s(I I)$ was well-recovered $\left(\mathrm{PM}_{10}\right.$ and $\mathrm{PM}_{2.5}$ on average $108 \%$ and $101 \%$, respectively). The extraction of the filter in combination with the sampled air matrix is likely to induce the As(III) conversion. The average measured As concentration in $\mathrm{PM}_{10}$ during a 40 -day monitoring campaign $\left(30 \mathrm{ng} \mathrm{m}^{-3}\right)$ at a hot spot location is above the European target value of $6 \mathrm{ng} \mathrm{m}^{-3}$. The measured As concentration in $\mathrm{PM}_{2.5}$ was half the value of the measured concentration in $\mathrm{PM}_{10}$ and no relative enrichment of total As was observed in either particulate matter fractions. However, in $\mathrm{PM}_{10}, \mathrm{As}(\mathrm{v})$ was the main component, while in $\mathrm{PM}_{2.5}$, As(III) was the dominant species. During the monitoring campaign, the fraction of particulate $\mathrm{As}(\mathrm{III})$ varied between 19 and $61 \%$ in $\mathrm{PM}_{10}$ and a trend towards a higher fraction of As(III) with increasing concentration of total As was observed. XANES and XRD analyses were used for the identification of arsenic species in local PM sources and confirmed the presence of $\mathrm{Ca}_{3} \mathrm{Sr}_{2}\left(\mathrm{AsO}_{4}\right)_{2.5}\left(\mathrm{PO}_{4}\right)_{0.5}(\mathrm{OH}), \mathrm{As}_{2} \mathrm{O}_{3}$ and $\mathrm{As}_{2} \mathrm{O}_{5}$ species.

\section{Introduction}

Notwithstanding the arsenic concentrations in particulate matter are generally quite low, typical arsenic levels for the European region are between 0.2 and $1.5 \mathrm{ng} \mathrm{m}^{-3}$ in rural areas and 0.5 and $3.0 \mathrm{ng} \mathrm{m}^{-3}$ in urban areas. In some hotspot regions increased concentration levels occur due to local industrial activities. ${ }^{1}$ Arsenic in atmospheric particulate matter exists in two oxidation states, $\mathrm{As}(\mathrm{III})$ and $\mathrm{As}(\mathrm{v})$, in inorganic and/or organometalloid forms. Five different species of As have been detected in ambient atmospheric particulate matter so far: ${ }^{2,3}$ the

${ }^{a}$ Flemish Institute for Technological Research (VITO), Boeretang 200, $2400 \mathrm{Mol}$, Belgium.E-mail: kristof.tirez@vito.be

${ }^{b}$ Flemish Environment Agency, Department Air, Environment and Communication, Unit Air, Kronenburgstraat 45, B-2000 Antwerp, Belgium

${ }^{c}$ Utrecht University, Inorganic Chemistry and Catalysis, Universiteitsweg 99, 3584 CG Utrecht, Netherlands

${ }^{d}$ Vienna University of Technology, Atominstitut, Stadionallee2, 1020 Vienna, Austria ${ }^{e} A N K A$, KIT, Eggenstein-Leopoldshafen, Germany two inorganic species arsenite (As(III)) and arsenate $(\mathrm{As}(\mathrm{v}))$ and the organoarsenic species methylarsonate (MA), dimethylarsinate (DMA) and trimethylarsine oxide (TMAO), all three methylated forms of As(v). TMAO has been identified as the predominant organoarsenical species in PM, with maximum concentrations up to $0.09 \mathrm{ng} \mathrm{m}^{-3}{ }^{2,3}$

Because of the relatively high toxicity and carcinogenicity of arsenic through inhalation, special attention is required to assess the health risks of arsenic in air. ${ }^{4}$ The two inorganic species, arsenite and arsenate, are reported to be more toxic than the organoarsenic species. There is also a toxicological difference between the two inorganic As species, where trivalent arsenic is considered to be the more toxic species. However, taking into account the difference within the variation of the toxicological data, the difference in toxicity, a factor of $2-3$, is considered small. ${ }^{4}$ As a result of adverse effects of exposure to air pollutants in ambient air, the European Union, amongst others, has developed an extensive body of legislation which establishes health based standards and objectives for a number of pollutants in air. For arsenic, a European target value of $6 \mathrm{ng}$ 
$\mathrm{m}^{-3}$ came into effect at the end of 2012 as an annual mean concentration. ${ }^{5}$

With regard to arsenic determination in ambient air, the European Committee for Standardisation (CEN) has published sampling and analysis procedures. The European reference method specifies a microwave digestion followed by analysis with either ICP-MS or ET AAS. ${ }^{8,9}$ For the determination of the individual species of arsenic, several combinations of techniques (separation + element-selective detection) have been attempted, but high-performance liquid chromatography (HPLC) in conjunction with ICP-MS or hydride generation atomic fluorescence spectrometry (HG-AFS) has emerged as one of the best combinations for monitoring purposes. ${ }^{1-3,6,7,10-23}$

Most arsenic analytical techniques require samples to be extracted or digested prior to instrumental analysis. This approach was used consistently in the majority of the literature reviewed when particulate matter was collected on filter media. ${ }^{6,12-22,24}$ In this case, the focus on the extraction procedure is the complete recovery of the arsenic species avoiding possible species inter-conversion (As(III) $\leftrightarrow \operatorname{As}(\mathrm{V}))$. Based on the literature, air samples were prepared in a variety of ways but, in nearly every case, wet digestion or extraction of the air sampling media was performed using an acid. For example, Oliveira et al. evaluated several extraction methods, comparing water, $\mathrm{NH}_{2} \mathrm{OH}, \mathrm{HCl}$, and $\mathrm{H}_{3} \mathrm{PO}_{4}$ digestion followed by either microwave or ultrasonic radiation; ${ }^{14}$ the $\mathrm{NH}_{2} \mathrm{OH}, \mathrm{HCl}$, and $\mathrm{H}_{3} \mathrm{PO}_{4}$ extraction procedures were all determined to be acceptable extraction methods. Sánchez de la Campa et al. performed sample digestion using $\mathrm{HNO}_{3}$ and $\mathrm{HF}$, as well as a $\mathrm{NH}_{2} \mathrm{OH}-\mathrm{HCl}$ digestion method incorporating microwave digestion. ${ }^{12}$ Tsopelas et al. evaluated $\mathrm{HCl}$ versus $\mathrm{H}_{3} \mathrm{PO}_{4}$ extraction of both polycarbonate and glass fiber filters; ${ }^{13}$ they determined that $\mathrm{HCl}$ led to a higher recovery from both filter types, and the HCl-polycarbonate filter was the optimal preparation method. Thus, although some differences in sample preparation approaches were identified in the articles reviewed, most seemed to be effective for determining speciated arsenic in air samples. A few studies compared multiple extraction methods in an attempt to identify the most efficient technique and to allow selection of the most robust methods. ${ }^{\mathbf{1 4 , 2 0}}$ Based on the studies reviewed, extraction of quartz fiber filters in $\mathrm{NH}_{2} \mathrm{OH}-\mathrm{HCl}$ or $\mathrm{HCl}$ appeared to be the optimal preparation method.

Certified reference materials (CRMs) are available for total arsenic and were evaluated in several studies to verify the recovery of the extraction procedure. ${ }^{26}$ For example, Tsopelas et al. reported recoveries for total As of $98-103 \%$ on a reference soil sample; ${ }^{13}$ Sanchez de la Campa et al. reported nearly $100 \%$ recovery of total As on coal fly ash (SRM 1633b):;2 Yang et al. reported recoveries for total As of $92 \%$ on a reference soil sample. ${ }^{1}$ However, in general, limited information is available on the identification and concentration of specific arsenic species in CRMs. ${ }^{15}$

Rabano et al. evaluated the species inter-conversion (As(III) $\leftrightarrow \operatorname{As}(\mathrm{v}))$ in several ways during their study. ${ }^{6,19}$ First, they evaluated the recovery of speciated arsenic standards on unexposed PFTE filters; recoveries were on the order of $95 \%$ and $100 \%$ for $\operatorname{As}(\mathrm{III})$ and $\operatorname{As}(\mathrm{v})$, respectively. This was followed by determination of recoveries of known concentrations of speciated arsenic standards added to exposed filters (similar to matrix spikes); recoveries of the standards were $79 \pm 22 \%$ and $97 \pm 23 \%$ for $\operatorname{As}(\mathrm{III})$ and $\mathrm{As}(\mathrm{v})$, respectively. The authors concluded that the complex nature of the PM slightly affected the measurement of the arsenic species; matrix interference may also have been an issue but, in general, recoveries were very good. Several of the studies reviewed evaluated the accuracy in terms of extraction efficiency, comparing the summed concentrations of speciated arsenic (i.e., $\mathrm{As}(\mathrm{III})+\mathrm{As}(\mathrm{V})$ ) to the total arsenic results and calculating \% recoveries. As an example, to evaluate the efficiency of their extraction procedures, Sánchez de la Campa et al. compared the results of $\mathrm{PM}_{2.5}$ to total arsenic in dry-ashed samples; comparing the sum of the As(III) and $\operatorname{As}(v)$, a mean extraction efficiency of $97 \%$ was found, indicating excellent recovery. ${ }^{12}$

As stated above, different extracting solutions have been used to perform the extraction of arsenic species. In these studies, the yield of extraction, the possible inter-conversion of As species, and their recoveries were sometimes evaluated by spiking with exogenous As(III) and As(v). The use of speciated isotope dilution mass spectrometry (SIDMS) to study possible arsenic species inter-conversions occurring during the extraction is not applicable. ${ }^{27-29}$ In the literature, the use of X-ray absorption near edge structure (XANES) spectroscopy as a benchmark for validation of extraction methods is often reported. ${ }^{29,30}$ XANES is a non-destructive element-specific technique for characterising electronic configurations of both amorphous and crystalline materials. ${ }^{31,32}$ In synchrotron-based characterisation of arsenic species in urban particulate matter and particulate matter derived from coal combustion, As(v) was reported to be the most dominant form..$^{33,34}$

Ambient air monitoring focuses on particulate matter, however and especially in the case of high temperature metallurgical processing, besides arsenic in particles, gaseous arsenic emissions may be of concern. Impregnated filters have been found to be able to capture simultaneously both particulate arsenic and arsenic oxide vapour and have been used for total arsenic collection, amongst others, in the vicinity of a copper smelter. ${ }^{25}$ The volatile arsenic trioxide can be collected by a reaction with the chemical agent on the impregnated filter, e.g. sodium carbonate $\left(\mathrm{As}_{2} \mathrm{O}_{3}+\mathrm{Na}_{2} \mathrm{CO}_{3} \rightarrow 2 \mathrm{NaAsO}_{2}+\mathrm{CO}_{2}\right)$ and thereafter, determination of the total arsenic content is performed. ${ }^{24,25}$ For example, the presence of arsenite, arsenate, arsenic sulfide and $\mathrm{As}_{2} \mathrm{O}_{3}$ vapours has been reported in copper smelter emissions. ${ }^{24}$

The work in this paper describes the determination of inorganic arsenic species in ambient particulate matter (PM) near a metallurgical industrial plant situated in Antwerp (Belgium), where according to recent modelling data (2011) the European target value of $6 \mathrm{ng} \mathrm{m}^{-3}$ is exceeded in an area of $c a$. $0.6 \mathrm{~km}^{2}$ with 3000 inhabitants. ${ }^{35}$ For this purpose a monitoring campaign was organized, where $\mathrm{PM}_{10}, \mathrm{PM}_{2.5}$ and arsenic vapours were collected on filters and the total element concentration of arsenic and its speciation were determined. The determination of total As concentration was performed using energy dispersive X-ray fluorescence spectrometry 
(EDXRF). The determination of particulate As(III) and As(v) was performed using microwave extraction in combination with HPLC/ICP-MS on one hand and XANES spectroscopy on the other.

\section{Experimental section}

\section{Sampling}

Sampling for total arsenic concentration in PM. Ambient particulate matter $\left(\mathrm{PM}_{10}\right.$ and $\left.\mathrm{PM}_{2.5}\right)$ was collected at 24 hour intervals in an urban area in the vicinity of a metallurgical site in the Flemish region of Belgium with a filter sampler (Leckel SEQ47/50 sequential sampler, Germany). Sampling was performed at a flow rate of $2.3 \mathrm{~m}^{3} \mathrm{~h}^{-1}$ on PTFE filters (Teflo $47 \mathrm{~mm}$, Pall Life Sciences).

Sampling for particulate As(III) and As(v). Ambient particulate matter $\left(\mathrm{PM}_{10}\right.$ and $\left.\mathrm{PM}_{2.5}\right)$ was collected at 24 hour intervals with a Partisol 40201 Speciation Sampler (Thermo Fisher Scientific Inc., Waltham, USA). Sampling was performed at a flow rate of $0.6 \mathrm{~m}^{3} \mathrm{~h}^{-1}$ on ashless cellulose filters (grade 40, Whatman International Ltd., Maidstone, UK).

Sampling for total As (particulate arsenic compounds and arsenic trioxide vapour). Sampling was performed according to NIOSH standard 7901 (1984), in which a methodology is described to collect particulate arsenic compounds as well as arsenic trioxide vapour. Air is sucked through a filter impregnated with a $20: 1 \mathrm{Na}_{2} \mathrm{CO}_{3}$ : glycerol solution. Sampling was performed with a Partisol 2300 Speciation Sampler (Thermo Fisher Scientific Inc.).

\section{Instrumentation}

Particulate As(III) and As(v) by HPLC/ICP-MS. For the determination of particulate As(III) and As(v), filters were extracted during 20 min with $100 \mathrm{mM}$ ascorbic acid and $1 \mathrm{M} \mathrm{H}_{3} \mathrm{PO}_{4}$ at 80 ${ }^{\circ} \mathrm{C}$ using microwave heating (Anton Paar, Multiwave 3000). After 10-fold dilution, extraction solutions were analysed using a quadrupole-based ICP-MS instrument (Nexion 300S, Perkin Elmer), equipped with an ESI MicroFlow PFA-ST concentric nebulizer (Elemental Scientific Inc. or ESI, NE, USA) coupled to a $50 \mathrm{ml}$ baffled cyclonic spray chamber (Perkin Elmer). The ICPMS operational parameters are summarized in Table 1. The speciation was carried out using a Flexar LC system (Perkin Elmer, Waltham, MA, USA) consisting of a Flexar Quaternary LC pump, a FXQ pump, a Flexar Solvent Manager and a Flexar LC autosampler. The speciation was carried out using a ESI CF-As01 column (ESI). ${ }^{36}$ The eluent was pushed through the column at a flow rate of $400 \mu \mathrm{L} \mathrm{min}^{-1}$ using a $50 \mu \mathrm{L}$ sample loop with the following program: $2.5 \mathrm{~min}$ eluent $1\left(1.06 \mathrm{ml} 25 \% \mathrm{NH}_{3}+1.36 \mathrm{ml}\right.$ $8.5 \% \mathrm{H}_{3} \mathrm{PO}_{4}$ in $\left.500 \mathrm{ml}\right) ; 6$ min eluent $2\left(1.05 \mathrm{ml} 25 \% \mathrm{NH}_{3}+3.41\right.$ $\mathrm{ml} 8.5 \% \mathrm{H}_{3} \mathrm{PO}_{4}$ in $\left.50 \mathrm{ml}\right) ; 8$ min eluent 1 . Cesium was added at a concentration level of $1 \mu \mathrm{g} \mathrm{L}^{-1}$ in both eluents and monitored along the chromatogram as an internal standard.

Total As (particulate arsenic compounds and arsenic trioxide vapour) by ICP-SFMS. For the determination of total As in PM, the NIOSH standard 7901 prepared filters were extracted during 20 min with $100 \mathrm{mM}$ ascorbic acid and $1 \mathrm{M} \mathrm{H}_{3} \mathrm{PO}_{4}$ min at $80^{\circ} \mathrm{C}$
Table 1 ICP-MS operating parameters

\begin{tabular}{ll}
\hline Parameter & Value \\
\hline RF power & 1500 \\
Plasma gas flow rate & $18 \mathrm{~L} \mathrm{~min}^{-1}$ \\
Auxiliary gas flow rate & $1.2 \mathrm{~L} \mathrm{~min}^{-1}$ \\
Nebulizer gas flow rate & $0.9-1.0 \mathrm{~L} \mathrm{~min}{ }^{-1}$ daily tuning \\
Deflector voltage & $-8.13 \mathrm{~V}$ \\
Discriminator threshold & 15 \\
RPq & 0.25 (standard) \\
Dwell time & $250 \mathrm{~ms}$ \\
Detector mode & Pulse \\
Measured $\mathrm{m} / \mathrm{z}$ & ${ }^{75} \mathrm{As} ;{ }^{133} \mathrm{Cs}$
\end{tabular}

using microwave heating. After 5-fold dilution, extraction solutions were analysed using inductively coupled plasma sector field mass spectrometry (ICP-SFMS, Element II, Thermo).

Total As in PM by EDXRF. The elemental concentration of As on the filters was measured using a high performance energy dispersive XRF spectrometer with polarised X-ray excitation geometry (HE XEPOS, Spectro Analytical Systems, Kleve, Germany). This instrument is equipped with a $50 \mathrm{~W}$ tungsten endwindow tube (max. 60 kV, $2 \mathrm{~mA}$ ) and a Silicon Drift Detector. For signal optimisation the used targets were $\mathrm{Mo}, \mathrm{Al}_{2} \mathrm{O}_{3}$, Co and $\operatorname{Pd}(\mathrm{L})$. The calibration of the XRF spectrometer was performed using in-house made standard filters. An in-house developed aerosol generation system based on the ultrasonic nebulisation of a multi-element solution was used for the collection of aerosols on a filter. ${ }^{37}$

XANES. XANES measurements were performed at the ANKA SUL-X Beamtime (Proposal ENV-247). XANES spectra are recorded by tuning the energy of incident X-ray photons across an absorption edge of a specific element present in the sample (here, As at the K-edge). The XANES contains information about the chemical state of the absorbing element. One common method (fingerprinting) is to compare the spectra of unknown samples. The X-ray source of SUL-X is a 27-pole wiggler operating at $K=8.5$ (wiggler gap, $16 \mathrm{~mm}$ ). A silicon (111) crystal pair with a fixed beam exit was used as the monochromator. The Xray beam was aligned with an intermediate focus, and finally focused by Kirkpatrick-Baez mirrors to about $100 \mathrm{~mm}$ (horizontal) $\times 20 \mathrm{~mm}$ (vertical) for measurements at the tidemark and to about $200 \mathrm{~mm}$ (horizontal) $\times 150 \mathrm{~mm}$ (vertical) for data acquisition. The fluorescence radiation was collected using a seven element $\mathrm{Si}(\mathrm{Li})$ solid-state detector (Gresham, now e2v) and a digital signal-processing system (DXP) from XIA. The absorption spectra were recorded summing all fluorescence emission counts within the As-Ka region of interest. The resulting XANES spectra were analyzed using ATHENA, which is included in the IFEFFIT package for XAS analysis. ${ }^{42-46}$ Each scan was normalized to an edge jump of unity and its energy scale was calibrated with respect to the Au-L3 edge. This energy calibration was based on the transmission of an elemental gold foil that was recorded simultaneously for each sample. The first maximum of the derivative of the Au XANES was calibrated to $11919 \mathrm{eV}$ (Au L3 edge) for each scan. The LSLC fitting range was 
restricted to -20 to $+50 \mathrm{eV}$ around the absorption edge (defined as the first maximum of the derivative).

XRD. The X-ray diffractograms were analysed with an X-Pert Pro from PANalytical (Eindhoven, Netherlands). The measurements were done on a standard sample holder. The measurement conditions were: Cu-K-alfa: $40 \mathrm{kV} ; 40 \mathrm{~mA}$; step $0.04^{\circ}$ 2theta; time: $4 \mathrm{~s}$; continuous scan. A monochromator and Soller slits were used combined with a spinner and a proportional detector.

\section{Standard solutions and reagents}

For the preparation of all solutions, ultra-pure water with a resistivity of $18 \mathrm{M} \Omega \mathrm{cm}^{-1}$ obtained from a Milli-Q water purification system (Millipore, MA, USA) was used.

Stock standard solutions for the calibration of the HPLC/ICPMS were prepared from $1 \mathrm{~g} \mathrm{~L}^{-1} \mathrm{As}(\mathrm{III})$ and As(v) standard solutions purchased from Chem-Lab (Zedelgem, Belgium). A stock standard solution of $10 \mathrm{mg} \mathrm{L}^{-1}$ As from Spex CertiPrep Inc. (NJ, USA) was used for the calibration of the ICP-SFMS. For the

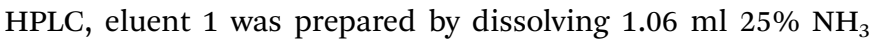
(Merck, Darmstadt Germany) and $1.36 \mathrm{ml} 8.5 \% \mathrm{H}_{3} \mathrm{PO}_{4}$ (Merck) in $500 \mathrm{ml}$ Milli-Q water. Eluent 2 was prepared by dissolving 1.05 $\mathrm{ml} 25 \% \mathrm{NH}_{3}$ and $3.41 \mathrm{ml} 8.5 \% \mathrm{H}_{3} \mathrm{PO}_{4}$ in $50 \mathrm{ml}$ Milli-Q water.

For the extraction solution $\mathrm{L}(+)$-ascorbic acid (BDH Prolabo, Leuven, Belgium) and $\mathrm{H}_{3} \mathrm{PO}_{4}$ (Merck) were used. For the sampling according to NIOSH standard 7901, filters were impregnated in a $50 \mathrm{ml} 85 \%$ glycerol (Merck) and $95 \mathrm{~g} \mathrm{Na}_{2} \mathrm{CO}_{3}$ (Merck) in $1 \mathrm{~L}$ Milli-Q water solution.

For XANES reference compounds, the following reagentgrade As compounds were purchased: $\mathrm{NaAsO}_{2}, \mathrm{As}_{2} \mathrm{O}_{5}, \mathrm{As}_{2} \mathrm{O}_{3}$, $\mathrm{As}_{2} \mathrm{~S}_{3}, \mathrm{FeAsS}$, and $\mathrm{Ca}_{3}\left(\mathrm{AsO}_{4}\right)_{2}$ (Alfa Aesar $\mathrm{GmbH}$, Karlsruhe, Germany). In addition, a residue produced at a lead refinery, $\mathrm{Ca}_{3}\left(\mathrm{AsO}_{4}\right)_{2}\left(135 \mathrm{~g} \mathrm{As} \mathrm{kg}^{-1}\right)$ and a fly ash sample (filtered by a bag filter) containing $\mathrm{As}_{2} \mathrm{O}_{3}\left(273 \mathrm{~g} \mathrm{As} \mathrm{kg}^{-1}\right)$ were collected at the monitoring site.

\section{Spiking of filters}

Ashless cellulose filters (grade $40,47 \mathrm{~mm}, 8 \mu \mathrm{m}$, Whatman International Ltd., Maidstone, UK) were selected for sample collection. The addition of As(III)/As(v) was performed by spiking with an automatic pipette $50-100 \mu \mathrm{l}$ of a prepared $\mathrm{As}(\mathrm{III}) / \mathrm{As}(\mathrm{V})$ solution (Chem-Lab) on the filter.

\section{Results and discussion}

\section{Performance characteristics of the HPLC/ICP-MS speciation monitoring method}

At first, the extraction according to Oliveira et al., also used by Sanchez-Rodas et al. for $\mathrm{PM}_{10}$ and by Sánchez de la Campa et al. for $\mathrm{PM}_{2.5}$ was evaluated. ${ }^{12,14,15}$ The procedure consists of microwave extraction $(150 \mathrm{~W})$ of the filter during 4 min with 100

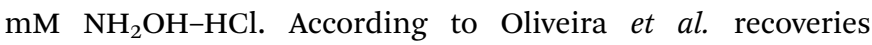
between 82 and $109 \%$ of the total arsenic content are to be expected..$^{14}$ However, the recovery of total As using this extraction procedure on 10 air filters collected at the sampling site ranged between 5 and $100 \%$. Therefore a more rigorous microwave extraction method as described by Sun et al. using $100 \mathrm{mM}$ ascorbic acid (used as an antioxidant) and $1 \mathrm{M} \mathrm{H}_{3} \mathrm{PO}_{4}$ during 20 min at $80^{\circ} \mathrm{C}$ was used. ${ }^{38,39}$

The accuracy of this procedure was verified by extracting NIST 2583 trace elements in indoor dust (certified value is $7.0 \pm$ $1.6 \mathrm{mg} \mathrm{kg}^{-1}$ As, but using digestion procedures an indicative mean of $5.2 \mathrm{mg} \mathrm{kg}^{-1}$ As is reported). An average As(III) concentration of $0.12 \pm 0.08 \mathrm{mg} \mathrm{kg}^{-1}(n=6)$ and average $\mathrm{As}(\mathrm{v})$ concentration of $5.85 \pm 0.27 \mathrm{mg} \mathrm{kg}^{-1}(n=6)$ were measured. The accuracy was further verified by comparing the total As content determined by EDXRF and the As(III) $+\mathrm{As}(\mathrm{v})$ content determined by HPLC/ICP-MS on $6 \mathrm{PM}_{10}$ air filters collected at the sampling site (see Table 2). The comparison of total As measured by EDXRF and total As calculated as the sum of measured As(III) and As(v) by HPLC/ICP-MS shows a good correlation (range 97-108\%).

In order to control possible species inter-conversion, separate solutions containing $5 \mu \mathrm{g} \mathrm{L} \mathrm{L}^{-1} \mathrm{As}(\mathrm{III})$ and $\mathrm{As}(\mathrm{v})$, respectively, were extracted with the above mentioned procedure and measured by HPLC/ICP-MS. An average As(III) concentration of $5.06 \pm 012 \mu \mathrm{g}$ $\mathrm{L}^{-1}(n=6$, RSD $2.4 \%$, bias $=+1.3 \%)$ and average As(v) concentration of $5.09 \pm 0.07 \mu \mathrm{g} \mathrm{L}^{-1}(n=6$, RSD $1.4 \%$, bias $=+1.8 \%)$ were derived. These results confirm that the extraction procedure itself does not induce arsenic species inter-conversion.

Based on 7 separate measurements of a 10 -fold dilution extraction solution (10 mM ascorbic acid $\left.+100 \mathrm{mM} \mathrm{H}_{3} \mathrm{PO}_{4}\right)$ containing $0.1 \mu \mathrm{g} \mathrm{L}^{-1} \mathrm{As}(\mathrm{III})$ and $\mathrm{As}(\mathrm{v})$, respectively, a limit of quantification $\left(6 \times\right.$ st. dev.) of 0.020 en $0.013 \mu \mathrm{g} \mathrm{L} \mathrm{L}^{-1}$ was derived for the HPLC/ICP-MS method. Taking into account the 10-fold dilution of the extraction solution and a sampled air volume of $14 \mathrm{~m}^{3}$ per filter, this corresponds to an LoQ of $0.34 \mathrm{ng} \mathrm{m}^{-3} \mathrm{As}$ (III) and $0.23 \mathrm{ng} \mathrm{m}^{-3} \mathrm{As}(\mathrm{v})$ for the monitoring method. The possible co-elution of As(III) with trimethylarsine oxide (TMAO) using an anion exchange column, leading to a possible overestimation of the As(III) concentration, has been recently reported. ${ }^{2,3}$ However, the maximum observed concentrations of TMAO in PM ( $0.09 \mathrm{ng}$ $\mathrm{m}^{-3}$ ) is below the LoQ of the monitoring method and negligible in the present case study.

Based on 26 duplicate measurements of extraction solutions of sampled filters, a relative precision ( $95 \%$ confidence interval) of $9.6 \%$ for $\operatorname{As}(\mathrm{III})$ and of $12.2 \%$ for $\mathrm{As}(\mathrm{v})$ was derived for the HPLC/ICPMS method. This is in line with reported precision in the literature, e.g., Rabano et al. reported precision error of $8 \%$ for unexposed filters versus $23 \%$ for exposed filters, based on the addition of speciated arsenic standards to these matrices. ${ }^{6,19}$ Šlejkovec et al. reported a study with an RSD of $<10 \%{ }^{17}$

The precision (st. dev.) of the ICP-SFMS method, used for the determination of total As (particulate arsenic compounds and arsenic trioxide vapour) according to NIOSH standard 7901, was verified by extracting NIST 2583 in every measurement run. An average total As concentration of $5.43 \pm 0.19 \mathrm{mg} \mathrm{kg}^{-1} \mathrm{As}(n=4)$ was found.

\section{Stability of the arsenic species}

Stability studies offer another potential method of evaluating accuracy. Based on our review, little information is available on 
Table 2 Comparison of total As measured by EDXRF and total As calculated as the sum of measured As(III) and As(V) by HPLC/ICP-MS

\begin{tabular}{|c|c|c|c|c|c|}
\hline & $\begin{array}{l}\text { EDXRF ng As } \\
\text { per filter }\end{array}$ & $\begin{array}{l}\text { HPLC/ICP-MS ng } \\
\text { As per filter }\end{array}$ & Recovery\% & $\begin{array}{l}\text { As(III) } \\
\text { ng As per filter }\end{array}$ & $\begin{array}{l}\mathrm{As}(\mathrm{v}) \\
\mathrm{ng} \text { As per filter }\end{array}$ \\
\hline Filter 1 & 2006 & 2167 & $108 \%$ & 804 & 1363 \\
\hline Filter 3 & 5696 & 5509 & $97 \%$ & 2010 & 3499 \\
\hline Filter 4 & 4777 & 4656 & $97 \%$ & 421 & 4235 \\
\hline Filter 5 & 1677 & 1680 & $100 \%$ & 278 & 1402 \\
\hline
\end{tabular}

the stability of arsenic species in air, but the oxidation of As(III) to $\mathrm{As}(\mathrm{v})$ in the atmosphere by oxidants such as ozone has been reported. ${ }^{13}$ Sánchez-Rodas et al. evaluated short- (within 1 day of sampling) and long- (sample analysed monthly for 1 year) term chemical stability in a sample exhibiting elevated arsenic concentrations; ${ }^{\mathbf{1 5}}$ no increase, decrease, or conversion of arsenic species (As(III) and As(v)) was noted. Oliveira et al. also evaluated sample stability for both total and speciated arsenic (As(III) and As(v)) after both extraction and speciation analyses. ${ }^{14}$ According to their findings, no changes in the distribution of arsenic species occurred during a 33 month period. Neither of these studies reported how the samples were stored during the stability analysis. Therefore, at least among these studies, the form of arsenic species in the sample appeared stable over time for a given method.

Stability of arsenic species during conservation. To study the stability of the arsenic species during conservation, filters were spiked in 4-fold with, respectively, As(III) and As(v) (at a level of $2000 \mathrm{ng}$ per filter) and stored under different conditions during 28 days at $<-18{ }^{\circ} \mathrm{C}$, at $<5{ }^{\circ} \mathrm{C}$ and at room temperature $\left(21{ }^{\circ} \mathrm{C}\right)$. The results are summarised in Fig. 1 . The results confirm the stability of As(III) and As(v) species over a period of 28 days, when preserved under $<5{ }^{\circ} \mathrm{C}$ conditions, and in the case of $\mathrm{As}(\mathrm{III})$, the need for keeping filters cool during storage.
Stability of arsenic species during sampling. To further study the stability of $\operatorname{As}(\mathrm{III})$ and $\mathrm{As}(\mathrm{v})$ species during sampling, 12 filters were spiked with As(III) (2000 ng per filter) and another set of 12 filters was spiked with As(v) (2000 ng per filter). Those filters were used in a preliminary sampling campaign (period 2$14 / 11 / 2013$ ) in the vicinity of the industrial site. At the same time, sampling was also performed on non-spiked filters in order to correct for the As species present in the sampled PM (local background concentration). The filters were sampled on a daily basis and were left on-site (in the sample holder) during the 12-day sampling campaign. The results are summarised in Table 3 . The recovery of the spikes was calculated as given in the following example: on 2/10/2013 the concentration of As(III) and $\mathrm{As}(\mathrm{v})$, respectively, on the non-spiked filter amounted 0.44 and $4.6 \mathrm{ng} \mathrm{m} \mathrm{m}^{-3}$. On the spiked filter (where a theoretical value of $36.3 \mathrm{ng} \mathrm{m}^{-3}$ As(III) was added), a concentration of As(III) and As(v) of 20.2 and $19.7 \mathrm{ng} \mathrm{m}^{-3}$, respectively, was measured. The As(III) recovery was calculated as $(20.2-0.44) / 36.3=54 \%$, the recovery for total As concentration of the spike, total As recovery $=(20.2+19.7-0.44-4.6) / 36.3=96 \%$. In Fig. 2 the recoveries for the spiked As(III), As(v) and total As are summarised.

More than $70 \%$ of the total content of the arsenic spike concentration is recovered in all cases. It must be mentioned that for the calculation of the recovery, the uncertainty includes

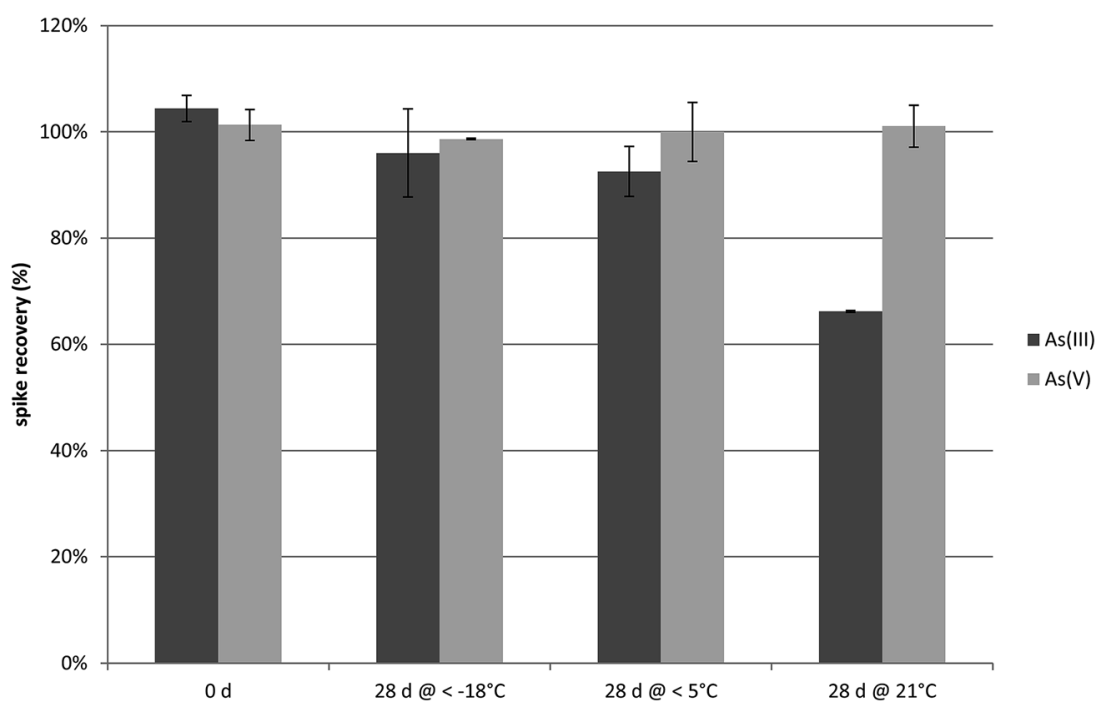

Fig. 1 Stability study of $\mathrm{As}(\mathrm{III})$ and $\mathrm{As}(\mathrm{V})$ spiked on filters ( $2 \mu \mathrm{g}$ per filter) and preserved during 0 days and 28 days under different conditions. The error bars represent the standard deviation on the measurement of 4 filters. 
the measurement as well as the sampling (two separate filters were used). A different stability is observed for the As species. No conversion from As(v) spike to As(III) spike is observed, while significant conversion from the As(III) to As(v) spike is observed during sampling. The As(III) spike is recovered as As(III) in the range of $45-65 \%$, while the remainder is oxidised to As(v). To further address the As(III) conversion, exogenous As(III) spiked filters were also processed during the final monitoring campaign.

\section{Results of the monitoring campaign (40 days)}

Monitoring setup. A daily monitoring campaign was organised between 7 November and 16 December 2013 in an urban area, in the vicinity of an industrial plant situated in Antwerp (Belgium), where according to modelling data of 2011, an exceedance of the European target value for arsenic of $6 \mathrm{ng} \mathrm{m}^{-3}$ was to be expected. ${ }^{35}$ During the campaign, the meteorological conditions were normal for the time of the year; an average temperature of $6{ }^{\circ} \mathrm{C}$, a precipitation of $55 \mathrm{~mm}$ and a wind mainly coming from the SW. During the campaign, the following parameters were determined: total $\mathrm{As}$ in $\mathrm{PM}_{10}$ and $\mathrm{PM}_{2.5}$ (PTFE filter/EDXRF), As(III) in $\mathrm{PM}_{10}$ and $\mathrm{PM}_{2.5}$ (Whatman filter, HPLC/ICP-MS), As(v) in $\mathrm{PM}_{10}$ and $\mathrm{PM}_{2.5}$ (Whatman filter, HPLC/ICP-MS), and total As (particulate arsenic compounds and arsenic trioxide vapour) in $\mathrm{PM}_{10}$ and $\mathrm{PM}_{2.5}$ (filter prepared according to NIOSH 7901/ICP-SFMS). During the monitoring campaign, $\mathrm{PM}_{10}$ was also sampled and analysed on a daily basis by two other laboratories. These laboratories used Wavelength Dispersive (WD) XRF and EDXRF for the determination of the total As content and cellulose nitrate and quartz filters for sampling, respectively.

As concentration in $\mathbf{P M}_{\mathbf{1 0}}$. In Fig. 3 an overview of the total As concentration in $\mathrm{PM}_{10}$ measured on a daily basis during the monitoring campaign is given. A good correlation is observed between the total As concentration determined by the three laboratories using different sampling units, different types of filter and different types of XRF instruments and the total As concentration in $\mathrm{PM}_{10}$ measured by HPLC/ICP-MS. Total As in $\mathrm{PM}_{10}$ was determined by HPLC/ICP-MS as the sum of the measured As(III) and As(v) concentration (for clarity, only results $>6 \mathrm{ng} \mathrm{m}^{-3}$ are shown in Fig. 3). For the EDXRF/WDXRF measurements, $55 \mathrm{~m}^{3}$ of air was sampled (Leckel), while in the case of HPLC/ICP-MS, $14 \mathrm{~m}^{3}$ of air was sampled (Speciation) within $24 \mathrm{~h}$. For the results $>6 \mathrm{ng} \mathrm{m}^{-3}$ (Fig. 3), a 84\% median recovery $(N=23)$ was found between particulate As collected on the ashless cellulose filter and measured by HPLC/ICP-MS on one hand and the average XRF result on the other.

Particulate arsenic compounds and arsenic trioxide vapour. During 11 days, a supplementary sampling set-up was performed in order to verify the presence of volatile As species $\left(\mathrm{As}_{2} \mathrm{O}_{3}\right.$ vapour). During this campaign, two filters were placed in series, the first consisted of an ashless cellulose filter (sampling of particulate $\mathrm{As}(\mathrm{III})$ and $(\mathrm{As}(\mathrm{V})))$ and the second filter was a $\mathrm{Na}_{2} \mathrm{CO}_{3}$ /glycerol solution impregnated ashless cellulose filter (sampling of arsenic trioxide vapour, NIOSH 7901). This set-up was used for $\mathrm{PM}_{10}$ as well as for $\mathrm{PM}_{2.5}$ sampling (see Tables 4 and 5). For the results $>6 \mathrm{ng} \mathrm{m}^{-3}$ reported in Tables 4 and 5 , a $84 \%$ median recovery $(N=9)$ for $\mathrm{PM}_{10}$ and a $86 \%$ median recovery $(N=6)$ for $\mathrm{PM}_{2.5}$ was found between particulate As collected on the ashless cellulose filter and measured by HPLC/ ICP-MS on one hand and the XRF (collected on the PTFE filter) result on the other.

The on average $15 \%$ lower results of particulate As collected on ashless cellulose filters and measured by HPLC/ICP-MS as compared to the XRF results collected on PTFE filters are in contrast to the results of the validation study on $6 \mathrm{PM}_{10}$ air filters collected at the sampling site (see Table 2), for which a good correlation was found (range 97-108\%). However, the results of the validation study were based on the analysis of the same filter. Therefore a filter efficiency test was performed to evaluate the particle retention of the ashless cellulose filter.

Table 3 Measured As(III) and As(v) concentrations during stability control sampling campaign

\begin{tabular}{|c|c|c|c|c|c|c|}
\hline \multirow[b]{2}{*}{ Sampling day } & \multicolumn{2}{|c|}{$\begin{array}{l}\text { Theoretical concentration added } \\
\text { spikes }\end{array}$} & \multicolumn{2}{|c|}{$\begin{array}{l}\text { Measured concentration non- } \\
\text { spiked filters }\end{array}$} & \multicolumn{2}{|c|}{$\begin{array}{l}\text { Measured concentration spiked } \\
\text { filters }\end{array}$} \\
\hline & $\operatorname{As}(\mathrm{III}) \mathrm{ng} \mathrm{m}^{-3}$ & $\operatorname{As}(\mathrm{v}) \mathrm{ng} \mathrm{m}^{-3}$ & $\operatorname{As}(\mathrm{III}) \mathrm{ng} \mathrm{m}^{-3}$ & $\operatorname{As}(\mathrm{v}) \mathrm{ng} \mathrm{m}^{-3}$ & $\operatorname{As}(\mathrm{III}) \mathrm{ng} \mathrm{m}^{-3}$ & $\operatorname{As}(v) n g m^{-3}$ \\
\hline $2 / 10 / 2013$ & 36.29 & & 0.44 & 4.56 & 20.2 & 19.7 \\
\hline $3 / 10 / 2013$ & & 36.32 & 0.40 & 3.39 & 0.5 & 39.4 \\
\hline $4 / 10 / 2013$ & 36.32 & & $a$ & $a$ & 23.6 & 28.3 \\
\hline $5 / 10 / 2013$ & & 36.30 & 3.64 & 5.42 & 3.1 & 39.9 \\
\hline $6 / 10 / 2013$ & 36.30 & & $a$ & $a$ & 22.4 & 15.8 \\
\hline $7 / 10 / 2013$ & & 65.00 & 54.93 & 42.81 & 52.3 & 89.8 \\
\hline $8 / 10 / 2013$ & 58.81 & & 5.08 & 15.44 & 40.1 & 35.8 \\
\hline 9/10/2013 & & 36.31 & $a$ & $a$ & 56.6 & 56.0 \\
\hline $10 / 10 / 2013$ & 36.29 & & 31.88 & 15.28 & 48.1 & 28.6 \\
\hline $11 / 10 / 2013$ & & 36.31 & 0.28 & 1.34 & 0.1 & 37.6 \\
\hline $12 / 10 / 2013$ & 36.30 & & $a$ & $a$ & 28.2 & 26.1 \\
\hline $13 / 10 / 2013$ & & 36.30 & 16.70 & 29.65 & 14.3 & 58.4 \\
\hline $14 / 10 / 2013$ & 85.95 & & 1.05 & 2.61 & 58.1 & 35.3 \\
\hline
\end{tabular}

${ }^{a}$ Measurements failed due to technical reasons. 


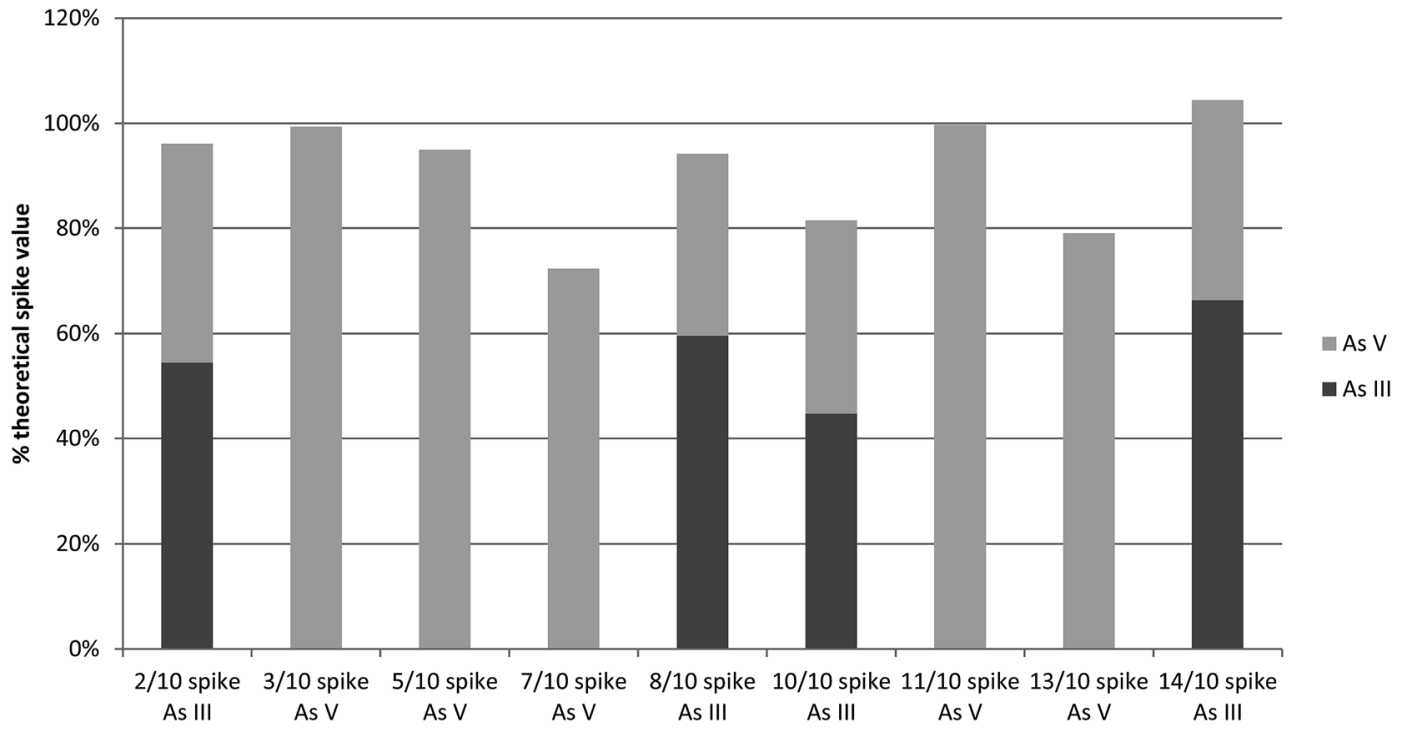

Fig. 2 Stability study of $A s(I I)$ and As(V) spiked on filters (2 $\mu \mathrm{g}$ per filter) during the sampling campaign.

With the use of 2 optical particle counters (Grimm 1.108 dust monitor (Grimm Technologies, Inc.) for the fine particles and a 8025 P-Trak (TSI, Inc.) for the ultrafine particles) a filter efficiency of approx. $85 \%$ for both fine and ultrafine particles was determined on a set of blank ashless cellulose filters in the lab. These results indicate that the amount of As found on the second filter might in fact be particulate As and not $\mathrm{As}_{2} \mathrm{O}_{3}$ vapour. The results reported as $\mathrm{As}_{2} \mathrm{O}_{3}$ vapour in Tables 4 and 5 can therefore be considered as an artefact of the sampling and the sum $\mathrm{As}(\mathrm{III})+\mathrm{As}(\mathrm{v})+\mathrm{As}_{2} \mathrm{O}_{3}$ vapour can be interpreted as consisting of particulate As only.
Inter-conversion of As species. In the stability study (see above), As(III) conversion up to 55\% was observed on spiked filters during sampling. In order to further study this As(III) oxidation, spiked As(III) filters were processed during this sampling campaign (in concentrations of 2000 and $1000 \mathrm{ng}$ As per filter). In order to calculate the recovery of the As(III) spike, sampling was also simultaneously performed on non-spiked filters (PM background concentration). Four control spiked filters were stored at $<-18{ }^{\circ} \mathrm{C}$ and extracted and analysed at the same time as the spiked filters that were sampled. No significant oxidation of As(III) was observed in the (non-sampled)

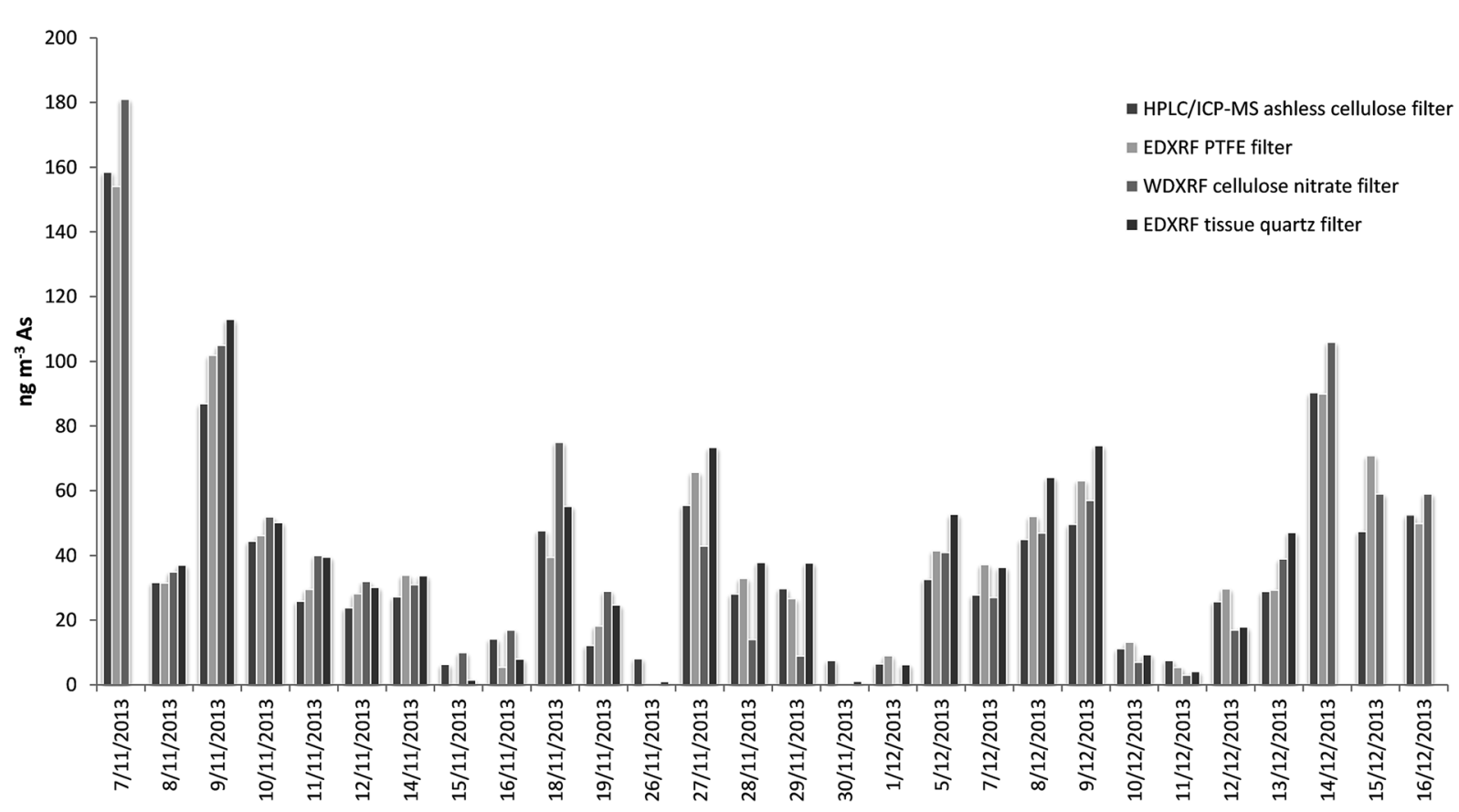

Fig. 3 Summary of and correlation between the different analytical methodologies for the determination of total As concentration in PM 10 during the monitoring campaign (for clarity, only results $>6 \mathrm{ng} \mathrm{m}^{-3}$ are represented). 
Table 4 Measurements of individual particulate As(III), As(v) by HPLC/ICP-MS, $\mathrm{As}_{2} \mathrm{O}_{3}$ vapour by ICP-SFMS and total As by EDXRF in PM 10 samples

\begin{tabular}{|c|c|c|c|c|c|}
\hline $\mathrm{PM}_{10}$ & $\operatorname{As}\left(\right.$ III) $\mathrm{ng} \mathrm{m}^{-3}$ & $\operatorname{As}(\mathrm{v}) \mathrm{ng} \mathrm{m}^{-3}$ & $\mathrm{As}_{2} \mathrm{O}_{3}$ vapour $^{a} \mathrm{ng} \mathrm{m} \mathrm{m}^{-3}$ & $\begin{array}{l}\mathrm{Sum} \mathrm{As}(\mathrm{III})+\mathrm{As}(\mathrm{v})+ \\
\mathrm{As}_{2} \mathrm{O}_{3} \text { vapour } \mathrm{ng} \mathrm{m}^{-3}\end{array}$ & XRF ng $\mathrm{m}^{-3}$ \\
\hline $7 / 11 / 2013$ & 93.8 & 64.8 & 5.3 & 163.9 & 167.5 \\
\hline $8 / 11 / 2013$ & 13.8 & 17.9 & 1.9 & 33.6 & 34.5 \\
\hline 9/11/2013 & 40.5 & 46.4 & 2.7 & 89.6 & 106.6 \\
\hline $10 / 11 / 2013$ & 9.1 & 35.3 & 1.5 & 46.0 & 49.5 \\
\hline $11 / 11 / 2013$ & 6.0 & 20.0 & 2.4 & 28.3 & 36.4 \\
\hline $12 / 11 / 2013$ & 5.9 & 17.9 & 2.4 & 26.2 & 30.1 \\
\hline $14 / 11 / 2013$ & 4.2 & 23.1 & 3.1 & 30.3 & 32.9 \\
\hline $15 / 11 / 2013$ & 1.9 & 4.4 & 2.4 & 8.7 & 5.8 \\
\hline $16 / 11 / 2013$ & 3.5 & 10.7 & 4.7 & 19.0 & 10.2 \\
\hline $17 / 11 / 2013$ & 1.3 & 3.6 & 3.4 & 8.3 & 5.1 \\
\hline $18 / 11 / 2013$ & 9.6 & 38.1 & 2.6 & 50.3 & 56.6 \\
\hline
\end{tabular}

control filters stored at $-18{ }^{\circ} \mathrm{C}$ and the recovered total concentrations were in good agreement with the theoretical values (see Table 6). The recoveries of the spiked As(III), calculated as the recovery of the total spiked As concentration and as the recovery of the As(III) species, are summarised in Table 7 for $\mathrm{PM}_{10}$ and Table 8 for $\mathrm{PM}_{2.5}$.

The total content of the spiked arsenic is well retrieved during the $\mathrm{PM}_{10}$ sampling (106-110\%). However, a significant portion of the As(III) spike is converted to As(v) (conversion varies between 0 up to $54 \%$ ) and these values are in line with the conversions observed in the preliminary sampling campaign performed in the stability study (see Fig. 2).

The total content of the arsenic spike is well retrieved during the $\mathrm{PM}_{2.5}$ sampling (average 101\%). Similar to the observations for $\mathrm{PM}_{10}$ sampling, a significant fraction of the As(III) is converted to $\mathrm{As}(\mathrm{v})$ (conversion varies between 8 and 53\%) (see also Fig. 4). It is remarkable that on two days, where (very limited) sampling was performed due to a defect in the sampling device (12/11 and 19/11) almost no conversions of the exogenously spiked As(III) are observed (7 and 1\%). This strongly indicates the effects of ambient sampling conditions and ambient particles on the $\mathrm{As}(\mathrm{III})$ recoveries and that the extraction of the filter in combination with the sampled air matrix is likely to induce the
As conversions. While this inter-conversion information is relevant for interpretation of the data, correction for the As(III) conversion itself is ambiguous because of the possible difference in oxidation between the added exogenous As(III) spike species and the As(III) species actually present in the sample. ${ }^{29}$

As in $\mathbf{P M}_{10}$ versus $\mathbf{P M}_{2.5}$. The average results of the measurements performed during the monitoring campaign are summarised in Table 9. The average concentration of As in the $\mathrm{PM}_{2.5}$ fraction ( $25 \mathrm{ng} \mathrm{m}{ }^{-3}$ ) is half the value of the $\mathrm{PM}_{10}$ fraction (50 $\mathrm{ng} \mathrm{m}^{-3}$ ) during the sampling period 7-18/11. The reported total As (HPLC/ICP-MS + ICP-SFMS) represents the sum of the particulate As(III) + As(v) measured by HPLC/ICP-MS and the arsenic collected on the second impregnated filter placed in series, which also represents particulate arsenic species caused by insufficient separation efficiency of the first filter (see discussion above, Tables 4 and 5), and measured by ICP-SFMS. Based on the simultaneous sampling of the $\mathrm{PM}_{10}$ en $\mathrm{PM}_{2.5}$ fractions, an average concentration of $c a .4 .1 \mathrm{ng}$ As per $\mu \mathrm{g} \mathrm{PM}_{10}$ and $4.2 \mathrm{ng}$ As per $\mu \mathrm{g} \mathrm{PM}_{2.5}$ was found (see Table 10). These results suggest that no relative enrichment is observed for total As in one of the particulate matter fractions as no significant difference is found between the amount of As per mass of PM for $\mathrm{PM}_{10}$ and $\mathrm{PM}_{2.5}$. An enrichment of arsenic in the fine

Table 5 Measurements of individual particulate As(III), As(v) by HPLC/ICP-MS, As ${ }_{2} \mathrm{O}_{3}$ vapour by ICP-SFMS and total As by EDXRF in PM L $_{2.5}$ samples

\begin{tabular}{|c|c|c|c|c|c|}
\hline $7 / 11 / 2013$ & 52.2 & 23.3 & 11.2 & 86.7 & 87 \\
\hline 9/11/2013 & 32.9 & 14.6 & 3.8 & 51.4 & 59 \\
\hline $10 / 11 / 2013$ & 3.8 & 10.0 & 1.3 & 15.1 & 13 \\
\hline $11 / 11 / 2013$ & 5.3 & 14.6 & 2.6 & 22.5 & 25 \\
\hline $15 / 11 / 2013$ & 2.1 & 6.4 & 3.2 & 11.7 & $<4$ \\
\hline $16 / 11 / 2013$ & 1.8 & 7.7 & 2.1 & 11.6 & $<4$ \\
\hline $17 / 11 / 2013$ & 1.7 & 3.8 & 3.4 & 9.0 & $<4$ \\
\hline $18 / 11 / 2013$ & 6.7 & 15.2 & 3.1 & 25.0 & 26 \\
\hline
\end{tabular}

${ }^{a}$ Artefact of the sampling. 
Table 6 Measurement results of the As(III) spiked control filters stored at $-18^{\circ} \mathrm{C}$

\begin{tabular}{lll}
\hline & $\begin{array}{l}\text { ng As(III) } \\
\text { per filter }\end{array}$ & $\begin{array}{l}\text { ng As(v) } \\
\text { per filter }\end{array}$ \\
\hline Filter spike $2 \mu \mathrm{g}$ As(III) & 2020 & 20 \\
Filter spike $2 \mu \mathrm{g}$ As(III) & 2070 & 20 \\
Filter spike $1 \mu \mathrm{g}$ As(III) & 1010 & 20 \\
Filter spike $1 \mu \mathrm{g}$ As(III) & 1040 & 10
\end{tabular}

fraction $\left(\mathrm{PM}_{2.5}\right)$ of airborne particulate matter was observed by Tsopelas et al. and Sanchez de la Campa et al. ${ }^{12,13}$

A similar calculation was performed to determine whether the contribution of $\mathrm{As}(\mathrm{III})$ is increased in the $\mathrm{PM}_{2.5}$ fraction compared to the $\mathrm{PM}_{10}$ fraction. The As(III) concentration (in $\mathrm{ng}$ $\mathrm{m}^{-3}$ ) was divided by the PM concentration (in $\mu \mathrm{g} \mathrm{m}^{-3}$ ), respectively, for $\mathrm{PM}_{10}$ and $\mathrm{PM}_{2.5}$ (see Table 10). The amount of $\mathrm{As}(\mathrm{III})$ is slightly enriched in the $\mathrm{PM}_{2.5}$ fraction. In $\mathrm{PM}_{10}, \mathrm{As}(\mathrm{v})$ is the main component, while in $\mathrm{PM}_{2.5}$, As(III) is the dominant species.

Fraction As(III) versus $\mathbf{A s}(\mathrm{v})$ in $\mathbf{P M}_{\mathbf{1 0}}$. The measurement results of the monitoring campaign show that there is a trend towards a higher fraction of As(III) with increasing concentrations of total As (see Table 11). This conclusion is visualised in Fig. 5, in which the As(III) percentage is given as a function of the wind direction and as a function of the total As-concentration. The industrial site was situated SW of the monitoring location. For the layout of this figure, daily monitored As concentrations of $\mathrm{PM}_{10}$ (total As and the percentage of As(III)) were merged to hourly wind direction measurements. Each combination of total As concentration (one daily averaged value) and hourly wind direction (24 measurements per day) are plotted as a pollution rose, where total As concentrations are given with respect to a concentric circle scaling (in $\mathrm{ng} \mathrm{\textrm {m } ^ { - 3 }} \mathrm{As}, 30 \mathrm{ng} \mathrm{m}^{-3}$ wide intervals) and wind directions with respect to the $\mathrm{N}, \mathrm{E}, \mathrm{S}$ and $\mathrm{W}$ axes $\left(10^{\circ}\right.$ wide intervals). The colouring of these 'bins' is in accordance with the percentage of As(III) of the total As concentration as represented by different colours (see legend).
At low concentrations of total As, the As(III) contribution is limited, with increasing concentration, the As(III) contribution increases as well.

\section{XANES analysis}

X-ray based techniques are generally regarded as reference methods for solid state speciation since they enable the identification and quantification of oxidation states while being non-destructive. ${ }^{31}$ A number of studies have been published on arsenic speciation with XANES. ${ }^{33,34,41}$ A great advantage of XANES is that it can distinguish between different compounds of the same element, including different oxidation states (e.g., $\mathrm{As}(\mathrm{III})$ and $\mathrm{As}(\mathrm{v}))$ as well as different compounds with the same oxidation state (e.g., $\mathrm{As}_{2} \mathrm{O}_{3}$ and $\mathrm{As}_{2} \mathrm{~S}_{3}$ ). For this study, the following reagent-grade As compounds were purchased: $\mathrm{As}_{2} \mathrm{O}_{5}$, $\mathrm{As}_{2} \mathrm{O}_{3}, \mathrm{As}_{2} \mathrm{~S}_{3}$, and $\mathrm{Ca}_{3}\left(\mathrm{AsO}_{4}\right)_{2}$. Besides those compounds, also an arsenic containing residue produced at the lead refinery and a fly ash sample (filtered by a bag filter), both originating from the metallurgical site, were analysed as well as they were likely to be representative for the sources of As pollution at the monitoring site.

Reference compounds. In a preliminary study, the residue produced at the lead refinery and the fly ash sample, both likely to represent sources of As at the monitoring site, were analysed by XRF, XRD and EXAFS to further elucidate the kind of arsenic species present.

In the fly ash sample, the following components were identified by XRD: $\mathrm{As}_{2} \mathrm{O}_{3}$ (arsenite), $\mathrm{Pb}_{5}\left(\mathrm{AsO}_{4}\right)_{3} \mathrm{Cl}$ (mimetite) and a structure isomorphous with tetragonal $\left(\mathrm{Sn}_{0.8} \mathrm{Sb}_{0.2}\right) \mathrm{O}_{2}$. The content of major elements, measured by EDXRF, amounted 270 $\mathrm{g} \mathrm{kg}^{-1}$ As, $190 \mathrm{~g} \mathrm{~kg}^{-1} \mathrm{Sb}, 190 \mathrm{~g} \mathrm{~kg}^{-1} \mathrm{~Pb}$ and $30 \mathrm{~g} \mathrm{~kg}^{-1} \mathrm{Sn}$. A qualitative evaluation of the EXAFS confirms the similarity between the reagent-grade $\mathrm{As}_{2} \mathrm{O}_{3}$ and the fly ash containing $\mathrm{As}_{2} \mathrm{O}_{3}$, only small structural differences might exist in the $1^{\text {st }}$ and $2^{\text {nd }}$ coordination shells: the As-O bond length seems a bit longer and the amplitude corresponding to the $\mathrm{O}$ atom at $3.45 \AA$ (O in the $\mathrm{As}_{4} \mathrm{O}_{6}$ cage) seems enhanced with respect to the amplitude corresponding to the $\mathrm{O}$ atom at $3.05 \AA$ (not in the $\mathrm{As}_{4} \mathrm{O}_{6}$ cage). This could be a hint that the $\mathrm{As}_{4} \mathrm{O}_{6}$ cages do exist

Table 7 Recovery of As(III)-spiked filters during the monitoring campaign $\left(\mathrm{PM}_{10}\right)$

\begin{tabular}{|c|c|c|c|c|c|c|}
\hline $\mathrm{PM}_{10}$ & & $\operatorname{As}(\mathrm{III}) \mathrm{ng} \mathrm{m}^{-3}$ & $\operatorname{As}(\mathrm{v}) \mathrm{ng} \mathrm{m}^{-3}$ & As spike $^{a} \mathrm{ng} \mathrm{\textrm {m } ^ { - 3 }}$ & Recovery total As (\%) & Recovery As(III) (\%) \\
\hline $05 / 12$ & Non spiked filter & 10.6 & 22.1 & & & \\
\hline $05 / 12$ & $1 \mu \mathrm{g} \mathrm{As(III)} \mathrm{spiked} \mathrm{filter}$ & 50.5 & 23.6 & 70 & $106 \%$ & $73 \%$ \\
\hline $07 / 12$ & Non spiked filter & 13.8 & 14.0 & & & \\
\hline $07 / 12$ & $2 \mu \mathrm{g}$ As(III) spiked filter & 102.1 & 47.8 & 139 & $108 \%$ & $74 \%$ \\
\hline $09 / 12$ & Non spiked filter & 24.1 & 25.6 & & & \\
\hline $09 / 12$ & $1 \mu \mathrm{g}$ As(III) spiked filter & 48.3 & 28.0 & 70 & $110 \%$ & $69 \%$ \\
\hline $11 / 12$ & Non spiked filter & 1.5 & 6.1 & & & \\
\hline $11 / 12$ & $2 \mu \mathrm{g}$ As(III) spiked filter & 139.0 & 11.0 & 139 & $108 \%$ & $100 \%$ \\
\hline $13 / 12$ & Non spiked filter & 7.4 & 21.5 & & & \\
\hline $13 / 12$ & $1 \mu \mathrm{g}$ As(III) spiked filter & 59.2 & 17.1 & 70 & $110 \%$ & $85 \%$ \\
\hline $15 / 12$ & Non spiked filter & 17.2 & 30.4 & & & \\
\hline $15 / 12$ & $2 \mu \mathrm{g}$ As(III) spiked filter & 64.1 & 84.1 & 139 & $107 \%$ & $46 \%$ \\
\hline
\end{tabular}

${ }^{a}$ Approx. $14.4 \mathrm{~m}^{3}$ was sampled on the spiked filters. 
Table 8 Recovery of As(III)-spiked filters during the monitoring campaign (PM 2.5$)$

\begin{tabular}{|c|c|c|c|c|c|c|}
\hline $\mathrm{PM}_{2.5}$ & & $\begin{array}{l}\text { As(III) } \\
\text { ng m }^{-3}\end{array}$ & $\begin{array}{l}\operatorname{As}(\mathrm{v}) \\
\mathrm{ng} \mathrm{m}^{-3}\end{array}$ & $\begin{array}{l}\text { As spike ng } \\
\mathrm{m}^{-3}\end{array}$ & $\begin{array}{l}\text { Recovery total } \\
\text { As }(\%)\end{array}$ & $\begin{array}{l}\text { Recovery } \\
\operatorname{As}(\text { III) (\%) }\end{array}$ \\
\hline $7 / 11$ & Non spiked filter & 52 & 23 & & & \\
\hline $8 / 11$ & Non spiked filter & 9 & 11 & & & \\
\hline $8 / 11$ & $2 \mu \mathrm{g}$ As(III) spiked filter & 91 & 68 & 140 & $100 \%$ & $59 \%$ \\
\hline 9/11 & Non spiked filter & 33 & 15 & & & \\
\hline $10 / 11$ & $2 \mu \mathrm{g}$ As(III) spiked filter & 72 & 79 & 137 & $99 \%$ & $49 \%$ \\
\hline $11 / 11$ & Non spiked filter & 5 & 15 & & & \\
\hline $11 / 11$ & $2 \mu \mathrm{g}$ As(III) spiked filter & 94 & 62 & 136 & $98 \%$ & $64 \%$ \\
\hline $14 / 11$ & Non spiked filter & $<0.4$ & 2 & & & \\
\hline $14 / 11$ & $2 \mu \mathrm{g}$ As(III) spiked filter & 83 & 71 & 138 & $109 \%$ & $60 \%$ \\
\hline $15 / 11$ & Non spiked filter & 2 & 6 & & & \\
\hline $17 / 11$ & $2 \mu \mathrm{g}$ As(III) spiked filter & 130 & 23 & 139 & $105 \%$ & $92 \%$ \\
\hline $18 / 11$ & Non spiked filter & 7 & 15 & & & \\
\hline $18 / 11$ & $2 \mu \mathrm{g}$ As(III) spiked filter & 129 & 32 & 143 & $100 \%$ & $88 \%$ \\
\hline $\mathrm{PM}_{2.5}$ & & $\begin{array}{l}\text { As(III) } \\
\text { ng per filter }\end{array}$ & $\begin{array}{l}\operatorname{As}(v) \\
\text { ng per filter }\end{array}$ & $\begin{array}{l}\text { As spike ng } \\
\text { per filter }\end{array}$ & $\begin{array}{l}\text { Recovery total } \\
\text { As }(\%)\end{array}$ & $\begin{array}{l}\text { Recovery } \\
\text { As(III) (\%) }\end{array}$ \\
\hline $12 / 11$ & Non spiked filter & 12 & 27 & & & \\
\hline $12 / 11$ & $2 \mu \mathrm{g}$ As(III) spiked filter & 1880 & 107 & 2000 & $97 \%$ & $93 \%$ \\
\hline $19 / 11$ & Non spiked filter & 20 & 67 & & & \\
\hline 19/11 & $2 \mu \mathrm{g}$ As(III) spiked filter & 2000 & 145 & 2000 & $103 \%$ & $99 \%$ \\
\hline
\end{tabular}

but their arrangement is less regular. The XANES and EXAFS collected for fly ash clearly suggest that fly ash is almost identical to cubic $\mathrm{As}_{2} \mathrm{O}_{3}$ (arsenolite), with a slightly changed crystalline structure and/or degree of crystallinity. In the remainder of this paper, this source will be denoted by $\mathrm{As}_{2} \mathrm{O}_{3}$ (fly ash).
The XRD analysis identified 3 components in the residue produced at the lead refinery. The main phase was $\left(\mathrm{Ca}_{8.40^{-}}\right.$ $\left.\mathrm{Sr}_{1.60}\right)\left(\mathrm{AsO}_{4}\right)_{2.58}\left(\mathrm{PO}_{4}\right)_{3.42}\left(\mathrm{~F}_{0.69}(\mathrm{OH})_{1.31}\right)$ corresponding to fermorite $\left(\mathrm{Ca}_{3} \mathrm{Sr}_{2}\left(\mathrm{AsO}_{4}\right)_{2.5}\left(\mathrm{PO}_{4}\right)_{0.5}(\mathrm{OH})\right)$. The other phases were identified as $\mathrm{Ca}(\mathrm{OH})_{2}$ (portlandite) and $\mathrm{Ca}\left(\mathrm{CO}_{3}\right)$ (calcite). The

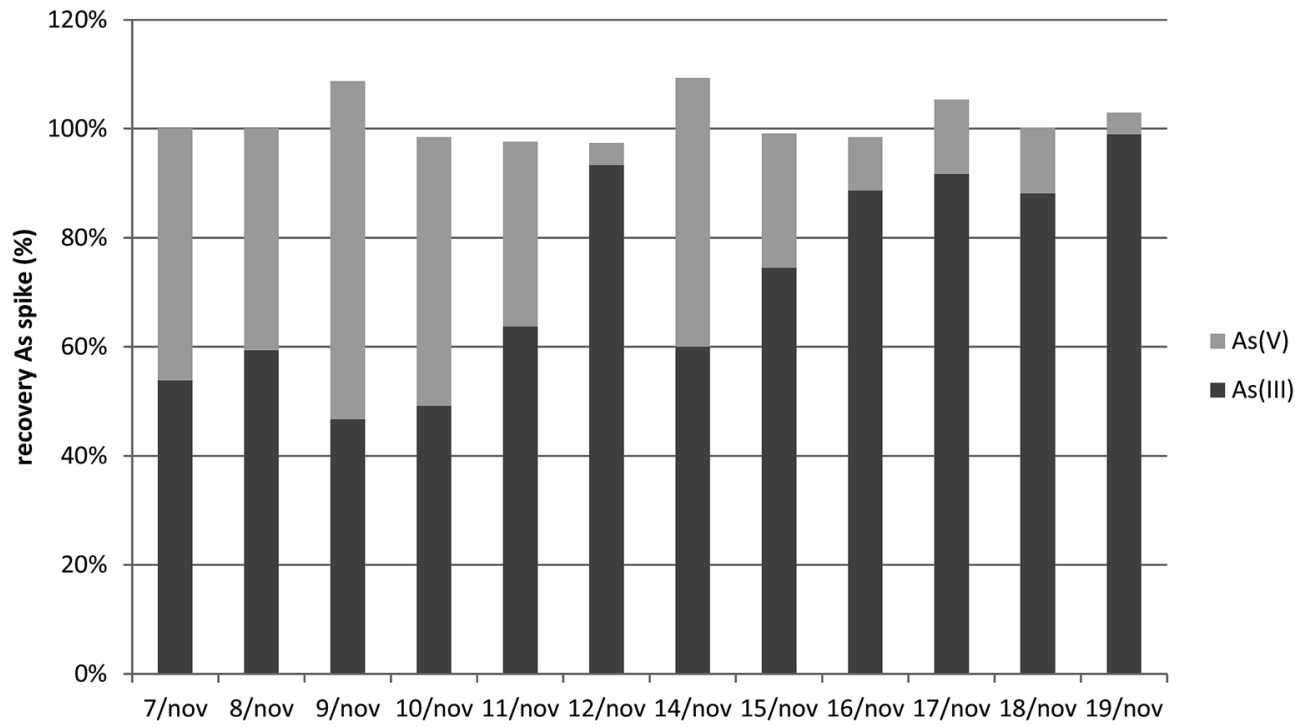

Fig. 4 Stability study of As(III) spiked on filters (2 $\mu$ g per filter) during the $\mathrm{PM}_{2.5}$ sampling campaign. 
Table 9 Average concentrations of total As, As(III) and As(v) in $\mathrm{PM}_{10}$ and $\mathrm{PM}_{2.5}$ during the monitoring campaign

\begin{tabular}{lllll}
\hline & \multicolumn{2}{l}{$7-18 / 11 / 2013$} & & \multicolumn{2}{l}{$7 / 11-16 / 12 / 2013$} \\
\cline { 2 - 3 } Species $\left(\mathrm{ng} \mathrm{m}^{-3}\right)$ & $\mathrm{PM}_{10}$ & $\mathrm{PM}_{2.5}$ & & $\mathrm{PM}_{10}$ \\
\hline Total As (XRF) & 50 & 25 & 33 \\
Total As (HPLC/ICP-MS + ICP-SFMS) & 47 & 28 & & 31 \\
Sum As(III) + As(v) (HPLC/ICP-MS) & 44 & 25 & & 29 \\
As(III) & 19 & 13 & & 12 \\
As(v) & 26 & 12 & & 18
\end{tabular}

content of major elements, measured by EDXRF, amounted to $260 \mathrm{~g} \mathrm{~kg}^{-1} \mathrm{Ca}, 140 \mathrm{~g} \mathrm{~kg}^{-1}$ As and $0.2 \mathrm{~g} \mathrm{~kg}^{-1} \mathrm{Sr}$. In the remainder of this paper, this source will be denoted as $\mathrm{Ca}_{3} \mathrm{Sr}_{2}\left(\mathrm{AsO}_{4}\right)_{2.5^{-}}$ $\left(\mathrm{PO}_{4}\right)_{0.5}(\mathrm{OH})$ (residue).

The reagent-grade As compounds $\mathrm{As}_{2} \mathrm{O}_{5}, \mathrm{As}_{2} \mathrm{O}_{3}, \mathrm{As}_{2} \mathrm{~S}_{3}$ and $\mathrm{Ca}_{3}\left(\mathrm{AsO}_{4}\right)_{2}$ were also analysed by XRD. All compounds were positively identified, except $\mathrm{Ca}_{3}\left(\mathrm{AsO}_{4}\right)_{2}$ which was identified as haidingerite, a calcium arsenate mineral with formula $\mathrm{Ca}\left(\mathrm{AsO}_{3} \mathrm{OH}\right) \cdot \mathrm{H}_{2} \mathrm{O}$.

Filters. At first, to check possible beam damage, a filter spiked with an As(III) standard solution was measured. Immediately after the start of a series of quick scans, a strong change in the scan curves was observed. A loop scan (1 s measurements at the same energy and point) at the whiteline of As(III) showed a rapid decline of As fluorescence radiation. When performing the analysis under vacuum conditions, no change of the As(III) XANES spectrum was observed. To reduce the impact of the beam only very short measurements were done on a single point on the sample. To improve statistics (signal-to-noise-ratio) several XANES measurements were spread over different points and merged together.

A description of the filters sampled in the vicinity of the industrial site and analysed by XANES are summarised in Table 12. Based on the modelling, the best fitting of the spectra was obtained using $\mathrm{As}_{2} \mathrm{O}_{5}, \mathrm{Ca}_{3} \mathrm{Sr}_{2}\left(\mathrm{AsO}_{4}\right)_{2.5}\left(\mathrm{PO}_{4}\right)_{0.5}(\mathrm{OH})$ (residue) and $\mathrm{As}_{2} \mathrm{O}_{3}$ (fly ash) as reference compounds. An example of the fitting with these reference compounds is given for filter $\mathrm{E}$ in Fig. 6. The relative contributions of the different As species as calculated based on the XANES measurements are summarised in Fig. 7. The $R$-factor of each fit (the quality of fit parameter commonly used in XANES analysis) is also shown in Fig. $7 .{ }^{45}$ In the 5 filters analysed by XANES, the fraction of the $\mathrm{Ca}_{3} \mathrm{Sr}_{2}$ $\left(\mathrm{AsO}_{4}\right)_{2.5}\left(\mathrm{PO}_{4}\right)_{0.5}(\mathrm{OH})$ residue $(\mathrm{As}(\mathrm{v}))$ varies between 23 and $44 \%$, the fraction of $\mathrm{As}_{2} \mathrm{O}_{3}(\mathrm{As}(\mathrm{III}))$ varies between 26 and $44 \%$ and the fraction of $\mathrm{As}_{2} \mathrm{O}_{5}(\mathrm{As}(\mathrm{v}))$ varies between 18 and 51\%. These results are in line with the fractions observed during the
Table 11 Median values of the fraction of $A s(I I)$ and $A s(v)$ in function of the total As-concentration in $\mathrm{PM}_{10}$

\begin{tabular}{lll}
\hline & $\begin{array}{l}\text { Median fraction } \\
\text { As(III) }\end{array}$ & $\begin{array}{l}\text { Median fraction } \\
\text { As(v) }\end{array}$ \\
\hline All data & $27 \%$ & $72 \%$ \\
$>6 \mathrm{ng} \mathrm{m}^{-3}$ total As conc. & $29 \%$ & $69 \%$ \\
$>30 \mathrm{ng} \mathrm{m}^{-3}$ total As conc. & $40 \%$ & $60 \%$ \\
$>60 \mathrm{ng} \mathrm{m}^{-3}$ total As conc. & $59 \%$ & $41 \%$
\end{tabular}

monitoring campaign (40 days), where the fraction of particulate $\mathrm{As}(\mathrm{III})$ varied between 19 and $61 \%$ in $\mathrm{PM}_{10}$ and $19-69 \%$ in $\mathrm{PM}_{2.5}$ (14 days).

Fraction As(III) versus As(v). At this point, two hypotheses may be formulated. First, in the gas cleaning systems with injection of lime that are used to capture volatile arsenic in metallurgical processing, the lime precipitates As(v) as hydroxyl and hydrated calcium arsenates. ${ }^{24}$ However, it has been reported that these compounds may not have long-term stability, showing that calcium arsenate compounds decompose slowly in contact with atmospheric $\mathrm{CO}_{2}$ to form calcium carbonate and

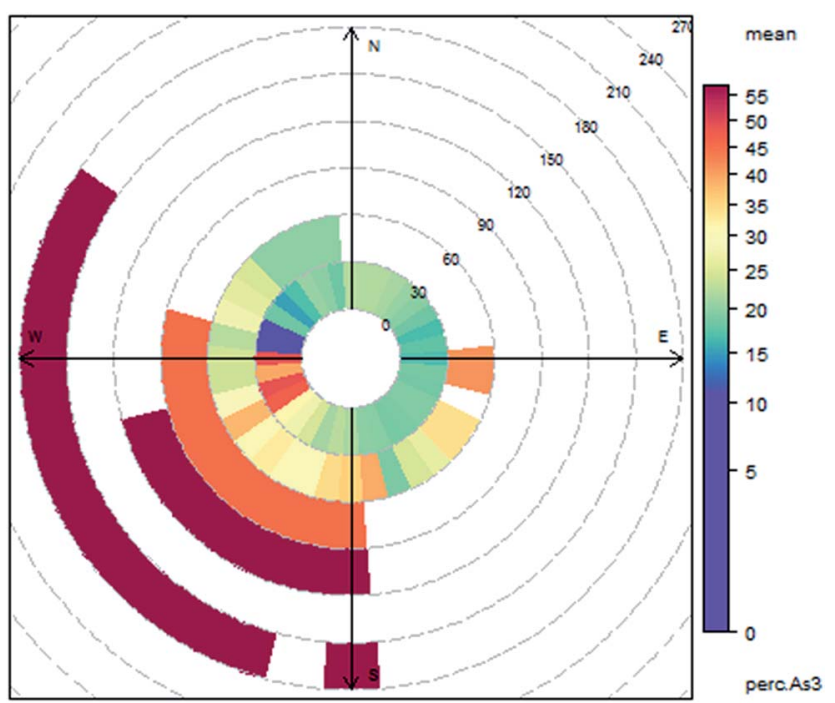

Fig. 5 Percentage As(III) of the total As-concentration in $\mathrm{PM}_{10}$ and in function of the wind direction at the sampling location, situated NE of the industrial plant. Total As concentrations are provided with respect to a concentric circle scaling (in $\mathrm{ng} \mathrm{m}^{-3} \mathrm{As}, 30 \mathrm{ng} \mathrm{m}^{-3}$ wide intervals) and wind directions with respect to the $N, E, S$ and $W$ axes $\left(10^{\circ}\right.$ wide intervals). The colouring of these 'bins' is in accordance with the percentage of As(III) of the total As concentration as represented by different colours (see legend).

Table 10 Amount of As per mass PM, for total $A s, A s(I I)$ and $A s(V)$ in $\mathrm{PM}_{10}$ and $\mathrm{PM}_{2.5}$ fractions

\begin{tabular}{|c|c|c|c|c|}
\hline $\mathrm{PM}_{2.5}$ & 4.4 & 4.0 & 2.0 & 1.5 \\
\hline $\mathrm{PM}_{10}$ & 4.2 & 3.9 & 1.7 & 2.0 \\
\hline
\end{tabular}


Table 12 Description of the filters analysed by XANES

\begin{tabular}{|c|c|c|c|c|c|}
\hline & Date sampling & Fraction & Filter & ng As per filter & $\mathrm{ng} \mathrm{\textrm {m } ^ { - 3 }}$ As \\
\hline Filter A & $24 / 06 / 2013$ & $\mathrm{PM}_{10}$ & PTFE & 820 & 14.9 \\
\hline Filter B & 1/07/2013 & $\mathrm{PM}_{2.5}$ & PTFE & 880 & 15.9 \\
\hline Filter D & $3 / 07 / 2013$ & $\mathrm{PM}_{10}$ & PTFE & 900 & 16.3 \\
\hline Filter E & $4 / 10 / 2013$ & $\mathrm{PM}_{10}$ & Ashless cellulose & 1180 & 25.4 \\
\hline
\end{tabular}

soluble arsenic acid. ${ }^{24}$ In this case it may be hypothesised that the fraction of $\mathrm{As}_{2} \mathrm{O}_{5}(\mathrm{As}(\mathrm{v}))$ results from the decomposition of the fraction $\mathrm{Ca}_{3} \mathrm{Sr}_{2}\left(\mathrm{AsO}_{4}\right)_{2.5}\left(\mathrm{PO}_{4}\right)_{0.5}(\mathrm{OH})$ residue (As(v)). Second hypothesis, based on the exogenous As(III) spiked filters, oxidation up to $\sim 50 \%$ in the case of $\mathrm{PM}_{10}$ and $\mathrm{PM}_{2.5}$ samples has been observed during the monitoring campaign and stability study. The hypothesis that the fraction $\mathrm{As}_{2} \mathrm{O}_{5}$, as calculated by XANES, originates from oxidation of $\mathrm{As}_{2} \mathrm{O}_{3}$ is therefore likely as well, and consequently, two scenarios can be calculated for the fraction of $\operatorname{As}(\mathrm{III})$ and $\operatorname{As}(\mathrm{V})$. In the first scenario, the fraction of $\mathrm{As}_{2} \mathrm{O}_{5}$ is included in the fraction of $\operatorname{As}(v)$; in the second scenario, it is assumed that $\mathrm{As}_{2} \mathrm{O}_{5}$ originates from oxidation of $\mathrm{As}_{2} \mathrm{O}_{3}$ and is therefore included in the $\mathrm{As}(\mathrm{III})$ fraction. The fact that proportionally more $\mathrm{As}_{2} \mathrm{O}_{5}$ is found in the samples collected in June-July (filter A-D) in comparison to the filter that was collected in October (filter $\mathrm{E}$ ), may be assigned to oxidation of $\mathrm{As}_{2} \mathrm{O}_{3}$ during prolonged storage or to decomposition of the $\mathrm{Ca}_{3} \mathrm{Sr}_{2}\left(\mathrm{AsO}_{4}\right)_{2.5}\left(\mathrm{PO}_{4}\right)_{0.5}(\mathrm{OH})$ residue, considering that XANES measurements were performed in November.
In the first scenario $\left(\mathrm{As}_{2} \mathrm{O}_{5}\right.$ originates from the decomposition of the $\mathrm{Ca}_{3} \mathrm{Sr}_{2}\left(\mathrm{AsO}_{4}\right)_{2.5}\left(\mathrm{PO}_{4}\right)_{0.5}(\mathrm{OH})$ residue), the fraction of particulate As(III) would vary between 18 and $51 \%$. In the second scenario $\left(\mathrm{As}_{2} \mathrm{O}_{5}\right.$ originates from the oxidation of $\left.\mathrm{As}_{2} \mathrm{O}_{3}\right)$, the fraction of particulate As(III) would vary between 62 and $77 \%$.

\section{Implications on toxicity}

Because of the relatively high toxicity and carcinogenicity of arsenic via inhalation, special attention is required to assess the health risks of arsenic in air. Most literature data on inhalation toxicity are related to studies in the workplace atmosphere. ${ }^{4,40} \mathrm{In}$ occupational exposure (smelters, chemical companies) the major form of arsenic is arsenic trioxide in the form of dust. There is convincing evidence that occupational exposure to arsenic via inhalation leads to an increased risk of lung cancer. Several studies also suggest that living near smelters or chemical plants where arsenic is processed an increased risk of lung cancer is expected. Several agencies have derived a unit risk for lung cancer by inhalation. In the derivation of the unit risks,

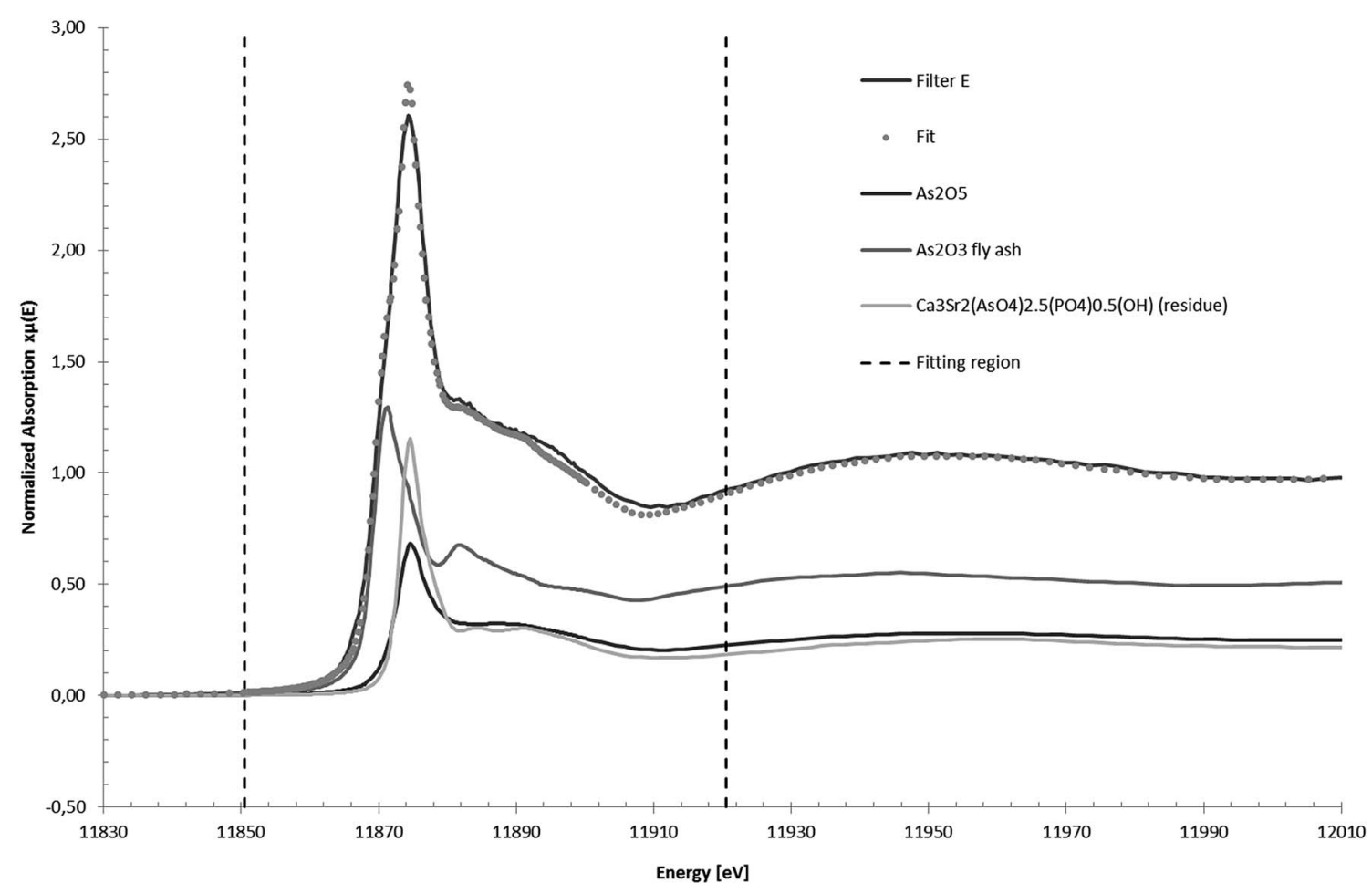

Fig. 6 XANES fitting of filter $\mathrm{E}\left(\mathrm{PM}_{10}, 1200 \mathrm{ng}\right.$ As per filter). 


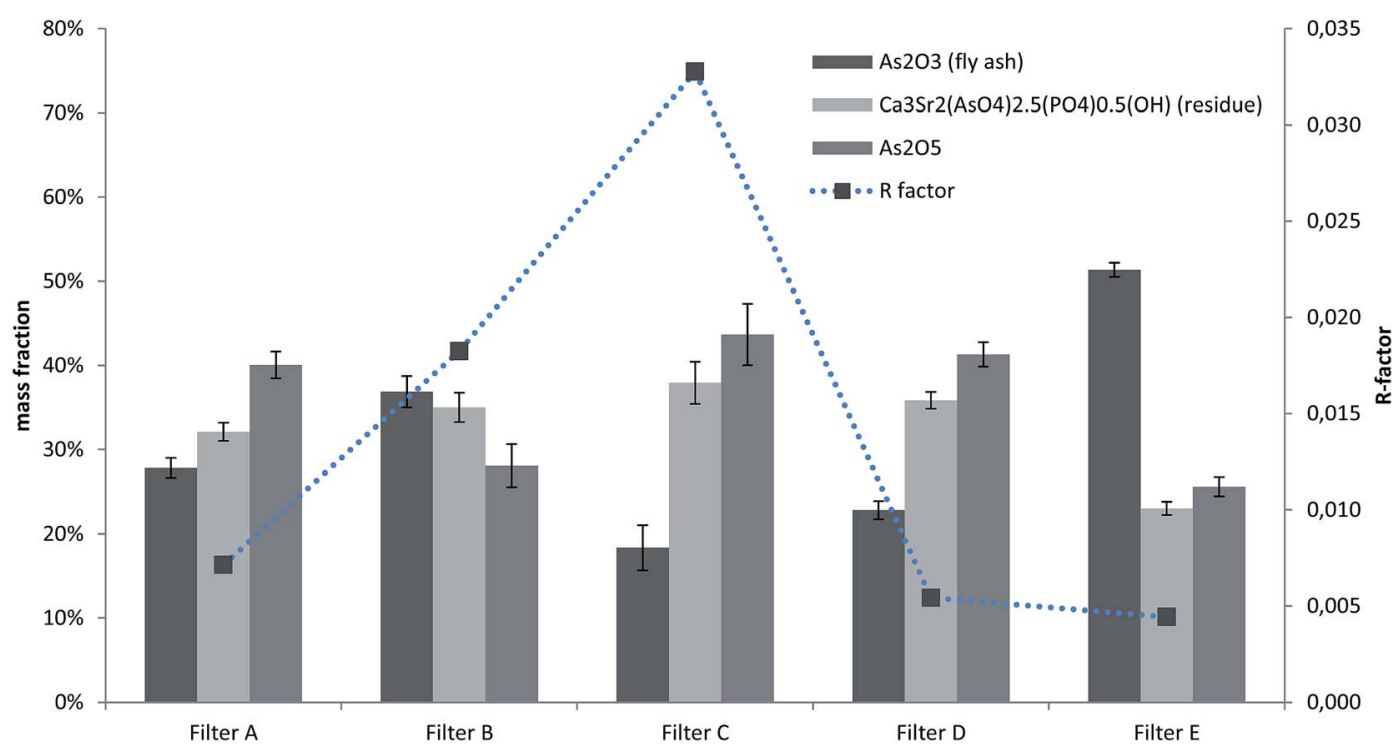

Fig. 7 Relative contributions of different As species in PM as calculated based on the XANES measurements (error bars represent the fit errors, which are calculated by the FEFFIT program (Newville, 1995) as described in the program documentation (Newville, 1998)).

differences in relative toxicity of arsenic species or particle size were not taken into account. ${ }^{4,40}$ As stated earlier, different agencies point to a factor 2-3 difference between $\mathrm{As}(\mathrm{III})$ and $\operatorname{As}(\mathrm{v})$, with a higher toxicity for As(III), but consider the difference within the uncertainty in the toxicity data. There is currently insufficient scientific information to derive a separate unit risk for smaller $\left(\mathrm{PM}_{2.5}\right)$ and for larger particles $\left(\mathrm{PM}_{10}\right)$. In accordance with this unit risks and for a population of 1000 persons exposed for lifetime to $1 \mu \mathrm{g} \mathrm{m}^{-3}$ As, there will be a risk of 0.15 to 4.29 additional cancer cases. ${ }^{40}$ For an additional lifetime cancer risk of 1 in 1 million lifetime-exposed persons, a number that is fixed in Europe for exposure calculations of the population, the corresponding air concentration with negligible cancer risk amounts to $0.23-6.7 \mathrm{ng} \mathrm{m}^{-3}$ As and is below the average concentration measured during this monitoring campaign. ${ }^{4}$

\section{Conclusion}

The developed HPLC/ICP-MS method allows monitoring of particulate $\mathrm{As}(\mathrm{III})$ and As(v)-species, with a LoQ of $0.34 \mathrm{ng} \mathrm{m}^{-3}$ $\mathrm{As}(\mathrm{III})$ and $0.23 \mathrm{ng} \mathrm{m}^{-3} \mathrm{As}(\mathrm{V})$, respectively. The precision $(95 \%$ confidence interval) of the method is $10 \%$ and good agreement is obtained between the sum of the concentrations of As(III) and As(v) determined by HPLC/ICP-MS and the total As concentrations determined by XRF (indication of a complete extraction of the As species). There were no conversions $\operatorname{As}(\mathrm{III}) \leftrightarrow \operatorname{As}(\mathrm{v})$ determined during the extraction and measurement of control solutions of both arsenic species. However, during sampling, significant conversion (oxidation) of exogenous spiked As(III) to $\operatorname{As}(\mathrm{v})$ was observed (conversion up to $54 \%$ in the case of $\mathrm{PM}_{10}$ and up to $53 \%$ in the case of $\mathrm{PM}_{2.5}$ ). The total content of the spiked $\mathrm{As}(\mathrm{III})$ was well-recovered $\left(\mathrm{PM}_{10}\right.$ and $\mathrm{PM}_{2.5}$ on average $108 \%$ and $101 \%$, respectively). This strongly indicates the effects of ambient sampling conditions and ambient particles on the As(III) recoveries and that the extraction of the filter in combination with the sampled air matrix is likely to induce the As conversions.

The average measured As concentration in $\mathrm{PM}_{10}\left(30 \mathrm{ng} \mathrm{m}^{-3}\right)$ at the hotspot location is above the European target value of 6 $\mathrm{ng} \mathrm{m}{ }^{-3}$. The measured As concentration in $\mathrm{PM}_{2.5}$ was half the value of the measured concentration in $\mathrm{PM}_{10}$, but no relative enrichment of total As was observed in one of both particulate matter fractions. However, in $\mathrm{PM}_{10}$, $\mathrm{As}(\mathrm{v})$ was the main component, while in $\mathrm{PM}_{2.5}$, As(III) was the dominant species. During the monitoring campaign (7/11-16/12/2013) the fraction of particulate As(III) varied between 23 and $63 \%$ and a trend towards a higher fraction of As(III) with increasing concentration of total As was observed. The ashless cellulose filter used for the sampling of the particulate arsenic species showed an insufficient separation efficiency $(\sim 85 \%)$ and biased the subsequent sampling of arsenic vapour $\left(\mathrm{As}_{2} \mathrm{O}_{3}\right)$. Based on the comparison of total As measurements by ICP-MS (including sampling for arsenic vapour) and XRF (only particulate As), the presence of arsenic vapour $\left(\mathrm{As}_{2} \mathrm{O}_{3}\right)$ at the sampling location is unlikely.

XANES and XRD analyses were used for the identification of arsenic species in local PM sources and confirmed the presence of $\mathrm{Ca}_{3} \mathrm{Sr}_{2}\left(\mathrm{AsO}_{4}\right)_{2.5}\left(\mathrm{PO}_{4}\right)_{0.5}(\mathrm{OH}), \mathrm{As}_{2} \mathrm{O}_{3}$ and $\mathrm{As}_{2} \mathrm{O}_{5}$ species. It was hypothesised that the fraction $\mathrm{As}_{2} \mathrm{O}_{5}$, as calculated by XANES, originated from oxidised $\mathrm{As}_{2} \mathrm{O}_{3}$ or the decomposition of calcium arsenate. The multi-disciplinary approach, including HPLC/ ICP-MS, XRF, XRD and XANES has shown to be a powerful tool to study and monitor arsenic speciation in ambient particulate matter.

\section{Acknowledgements}

We thank Wilfried Brusten, Filip Beutels, Annick Cluyts, Ellen Poelmans, Karlien Duyssens, Jef Daems, and Jo van Laer for 
their aid in the experimental and sampling work. We thank the Flemish Environment Agency for authorization to sample at their monitoring site. The monitoring campaign was commissioned, financed and steered by the Flemish Environment Agency.

\section{References}

1 G. Yang, L. Ma, D. Xu, J. Li, T. He, L. Liu, H. Jia, Y. Zhang, Y. Chen and Z. Chai, Chemosphere, 2012, 87, 845-850.

2 R. Jakob, A. Roth, K. Haas, E. M. Krupp, A. Raab, P. Smichowski, D. Gomez and J. Feldmann, J. Environ. Monit., 2010, 12, 409-416.

3 T. Tziaras, S. Pergantis and E. Stephanou, Poster Presented at the European Winter Conference on Plasma Spectrochemistry, Münster, Germany, 2015.

4 EC (2001), Ambient air pollution by $\mathrm{As}, \mathrm{Cd}$ and $\mathrm{Ni}$ compounds - position paper, ISBN 92-894-2054-5 European Commission, DG Environment, Working Group On Arsenic, Cadmium And Nickel Compounds, p. 315.

5 Directive 2008/50/EC of the European Parliament and of the Council of 21 May 2008 on ambient air quality and cleaner air for Europe.

6 A. S. Lewis, K. R. Reid, M. C. Pollock and S. L. Campleman, J. Air Waste Manage. Assoc., 2012, 62, 2-17.

7 B. Radke, L. Jewell and J. Namieśnik, Crit. Rev. Anal. Chem., 2012, 42, 162-183.

8 M. Gerboles, D. Buzica, R. J. C. Brown, R. E. Yardley, A. Hanus-Illnar, M. Salfinger, B. Vallant, E. Adriaenssens, N. Claeys, E. Roekens, K. Sega, J. Jurasović, S. Rychlik, E. Rabinak, G. Tanet, R. Passarella, V. Pedroni, V. Karlsson, L. Alleman, U. Pfeffer, D. Gladtke, A. Olschewski, B. O'Leary, M. O'Dwyer, D. Pockeviciute, J. Biel-Ćwikowska and J. Turšič, Atmos. Environ., 2011, 45(20), 3488-3499.

9 EN 14902:2005-Ambient air quality - Standard method for the measurement of $\mathrm{Pb}, \mathrm{Cd}$, As, and $\mathrm{Ni}$ in the $\mathrm{PM} 10$ fraction of suspended particulate matter.

10 I. Komorowicz and D. Barałkiewicz, Talanta, 2011, 84, 247261.

11 J. L. Gomez-Ariza, D. Sanchez-Rodas, I. Giraldez and E. Morales, Talanta, 2000, 51, 257-268.

12 A. M. Sánchez de la Campa, J. D. de la Rosa, D. SánchezRodas, V. Oliveira, A. Alastuey, X. Querol and J. L. GómezAriza, Atmos. Environ., 2008, 42, 6487-6495.

13 F. Tsopelas, L. Tsakanika and M. Ochsenkuhn-Petropoulou, Microchem. J., 2008, 89, 165-170.

14 V. Oliveira and J. L. Gómez-Ariza, Anal. Bioanal. Chem., 2005, 382, 335-340.

15 D. Sánchez-Rodas, A. M. Sanchez de la Campa, J. D. de la Rosa, V. Oliveira, J. L. Gómez-Ariza, X. Querol and A. Alastuey, Chemosphere, 2007, 66, 1485-1493.

16 M. M. Farinha, Z. Slejkovec, J. T. van Elteren, H. T. Wolterbeck and M. C. Freitas, J. Atmos. Chem., 2004, 49, 343-353.

17 Z. Šlejkovec, I. Salma, J. T. van Elteren and E. Zemplen-Papp, Fresenius' J. Anal. Chem., 2000, 366, 830-834.
18 P. A. Solomon, S. L. Altshuler and M. L. Keller, J. Air Waste Manage. Assoc., 1993, 43, 765-768.

19 E. S. Rabano, N. T. Castillo, K. J. Torre and P. A. Solomon, JAPCA, 1989, 39, 76-80.

20 H. Mukai and Y. Ambe, Anal. Chim. Acta, 1987, 193, 219-229.

21 H. Mukai and Y. Ambe, Atmos. Environ., 1987, 21, 185-189.

22 D. L. Johnson and R. S. Braman, Chemosphere, 1975, 4, 333338.

23 J. Morton and E. Leese, Anal. Bioanal. Chem., 2011, 399, 1781-1788.

24 L. Helsen, Environ. Pollut., 2005, 137, 305-315.

25 P. R. Walsh, R. A. Duce and J. L. Fasching, Environ. Sci. Technol., 1977, 11(2), 163-166.

26 R. Rubio, M. J. Ruiz-Chanco and J. F. Lopez-Sanches, Trends Anal. Chem., 2011, 29(201), 53-69.

27 H. M. Kingston "Skip", D. Hou, Y. Lu and S. Chalk, Spectrochim. Acta, Part B, 1998, 53(2), 299-309.

28 Q. Meng, Z. Fan, B. Buckley, L. Lin, L. Huang, et al., Atmos. Environ., 2011, 45, 2021-2027.

29 K. Tirez, G. Silversmit, N. Bleux, E. Adriaensens, E. Roekens, K. Servaes, C. Vanhoof, L. Vincze and P. Berghmans, Atmos. Environ., 2011, 45, 5332-5341.

30 J. Malherbe, M. P. Isaure, F. Seby, R. P. Watson, P. RodriguezGonzalez, P. E. Stutzman, C. W. Davis, C. Maurizio, N. Unceta, J. R. Sieber, S. E. Long and O. F. X. Donard, Environ. Sci. Technol., 2011, 45(24), 10492-10500.

31 S. Wang and C. N. Mulligan, Environ. Int., 2008, 34, 867-879.

32 U. E. A. Fittschen, F. Meirer, C. Streli, P. Wobrauschek, J. Thiele, G. Falkenberg and G. Pepponi, Spectrochim. Acta, Part B, 2008, 63, 1489-1495.

33 A. Godelitsas, P. Nastos, T. J. Mertzimikes, K. Toli, R. Simon and J. Göttlicher, Nucl. Instrum. Methods Phys. Res., Sect. B, 2011, 269, 3077-3081.

34 P. Shah, V. Strezov, C. Stevanov and P. F. Nelson, Energy Fuels, 2007, 21, 506-512.

35 Flemish Environment Agency (VMM), Air quality in the Flemish Region - Annual immission monitoring network 2013 (Dutch), 214 p, https:/www.vmm.be/publicaties/ luchtkwaliteit-in-het-vlaamse-gewest-jaarverslagimmissiemeetnetten-2013, last accessed on May 2015.

36 Elemental Scientific, application note, Low-Pressure Arsenic Speciation using the SC-DX chromFAST System with ICPMS Detection, http://www.icpms.com/products/chromfast-asspeciation.php, last accessed on May 2015.

37 C. Vanhoof, H. Chen, P. Berghmans, V. Corthouts, N. de Brucker and K. Tirez, X-Ray Spectrom., 2003, 32(2), 129-138. 38 M. Sun, G. Liu, Q. Wu and W. Liu, Talanta, 2013, 106, 8-13. 39 R. Saadawi, O. Hachmoeller, M. Winfough, T. Hanley, J. A. Caruso and J. A. Landero Figueroa, J. Anal. At. Spectrom., 2014, 29, 2146-2158.

40 DECOS, Dutch Expert Committee on Occupational Safety, a Committee of the Health Council of The Netherlands, 2012, Arsenic and inorganic arsenic compounds, Healthbased calculated occupational cancer risk values.

41 F. Meirer, G. Pepponi, C. Streli, P. Wobrauschek, V. G. Mihucz, G. Zaray, V. Czech, J. A. C. Broekaert, 
U. E. A. Fittschen and G. Falkenberg, X-Ray Spectrom., 2007, 36, 408-412.

42 M. Newville, et al., Phys. B, 1995, 208-209, 154-156.

43 M. Newville, 1998, FEFFIT - Using FEFF to model XAFS data, Chapter 5, Goodness of Fit and Uncertainties in the
Variables, downloaded April 1st 2012 from http:// cars9.uchicago.edu/ newville/feffit/.

44 M. Newville, J. Synchrotron Radiat., 2001, 8, 322-324.

45 B. Ravel and M. Newville, J. Synchrotron Radiat., 2005, 12, 537-541.

46 M. Newville, IFEFFIT, 2009, http://cars9.uchicago.edu/ifeffit/. 